\title{
I6. Yüzyılda Bir Osmanlı Para Birimi: Kara(ca) Akçe
}

Şule Pfeiffer-Taş:

An Ottoman Unit of Currency in the $16^{\text {th }}$ Century: Kara(ca) Akçe

Abstract $\square$ The problem addressed in this research is to determine the currency, called kara ( $c a$ a aç̧e in the documents, which the Ottoman state used in the east of Anatolia during the 16th century. Except for a brief reference by Sahillioğlu, there is not much information about this akçe. For this reason, whether kara(ca) akçe was also an accounting coin and a currency in circulation along with the Osmanî akçe will be discussed. The value of the kara (ca) akçe in the face of the Ottoman akçe is found in various documents such as the Ottoman Laws, Şeriyye Sicilleri and Mühimme Registry, together with current exchange prices against other currencies such as gold, kuruş etc. When this information is evaluated chronologically within the framework of the developments in Ottoman monetary history, there is a relationship proportional to the weight of the Ottoman akçe. In recent research on the Ottoman numismatics at the end of the 16th century, it was found that the official weight in some Eastern mints was $1 / 4$ lower than that of Ottoman akçe. These akçes differ in stylistic terms from other mints defined as the Anatolian and Rumelia groups and are named the Eastern group. Especially in the Ottoman documents related to tax and trade, the existence of this currency, which is $1 / 4$ lower than the exchange rate against the Osmanî akçe, is noteworthy. In this study, an attempt will be made to prove that this coin was not only a currency that determined the exchange rate, but it was also in circulation.

Keywords: Ottoman monetary history, akçe, economic history, 16th century, trade, numismatics.

Bu araştırmada, Osmanlı Kanunnameleri, Şeriyye Sicilleri, Mühimme defterleri gibi farklı kaynaklarda kara(ca) akçe olarak adlandırılan para biriminin, numizmatik araştırmalarda varlığı tespit edilen Osmanlı akçesinin resmi vezninden

* Atılım Üniversitesi. 
daha düşük ağırlığa sahip, Doğu grubu olarak adlandırılan akçeler ile özdeş olduğunu kanıtlamaya yönelik veriler birlikte değerlendirilecektir. ${ }^{1}$ Kara(ca) akçe ile ilgili bilgilere ve yorumlara geçmeden önce, 16. yüzyılda Osmanlı para tarihi ile ilgili gelişmelere bakmakta fayda vardır.

\section{Numizmatik Veriler}

\section{I.1. 16. Yüzyılda Osmanlı Akçesi Ayarı ve Vezni Hakkında Yeni Veriler}

Osmanlı para tarihinin en önemli dönemlerinden biri olan 16. yy. daki gelişmeler literatürde yazılı kaynaklara ve genellikle tekil olarak incelenen sikkelerin sınırlı katalog bilgilerine dayandırılarak, ekonomi tarihi bağlamında ele alınmıştır. ${ }^{2}$ Ancak, 2000 yılında Rahmi Hüseyin Ünal başkanlığında Beçin Kalesi'nde

1 Numizmatik veriler ve ve kara(ca) akçe terimi ile olası bağlantısı konusunda bkz. Şule Pfeiffer-Taş, "16. Yüzyılda Bir Osmanlı Para Birimi: Kara(ca) Akçe/ An Ottoman Currency in 16th Century: Kara(ca) Akçe", 12th International Congress of Ottoman Economic and Social History (ICOSEH) 11-15 July 2011, Retz (Lower Austria), Abstracts, s. 66-67; kongrede sunulan bildirilerin tam metninin yayınlanması öngörülmediği için bildiri genişleterek bu makale hazırlanmıştır. Kısa bir bilgi için ayrıca bkz. Şule Pfeiffer-Taş ve Nikolaus Schindel, "The Beçin Coin Hoard and Ottoman Monetary History in the Late 16 ${ }^{\text {th }} /$ Early $17^{\text {th }}$ Century", Journal of the Economic and Social History of the Orient, 56, 4-5 (2013), s. 653-671; ancak bu çalışma Osmanlı belgelerinden ulaşılan kapsamlı bilgileri ve değerlendirmeleri içermemektedir.

2 Bu konuda bkz. Ömer Lütfi Barkan, "Onaltıncı Asrın İkinci Yarısında Türkiyede Fiyat Hareketleri”, Belleten, XXXIV/136 (1970), s. 557-607. Ömer Lütfi Barkan, "The Price Revolution of the Sixteenth Century: A Turning Point in the Economic History of the Near East", trans. Justin McCarthy, International Journal of the Middle East Studies, 6 (1975), s. 3-28; Özer Ergenç, "XVI. Yüzyılın Sonlarında Osmanlı Parası Üzerinde Yapılan İşlemlere İlişkin Bazı Bilgiler”, Türkiye İktisat Tarihi Üzerine Araştırmalar, ODTÜ Gelişme Dergisi Özel Sayısı, (1978), s. 86-97; Halil Sahillioğlu, "Osmanlı Para Tarihinde Dünya Para ve Maden Hareketinin Yeri 1300-1750”, ODTÜ Gelişme Dergisi, Özel Sayısı (1978), s. 1-38; Haim Gerber, "The Monetary System of the Ottoman Empire", Journal of the Economic and Social History of the Orient, 25 (1982), s. 308-24; Huri İslamoğlu-İnan, The Ottoman Empire and the World-Economy, (Cambridge: Cambridge University Press, 1987); Halil İnalc1k, An Economic and Social History of the Ottoman Empire. Volume One 1300-1600 (Cambridge: Cambridge University Press, 1994); Halil İnalcık, Suraiya Faroqhi, Bruce McGowan, Donald Quataert, Şevket Pamuk (eds.), An Economic and Social History of the Ottoman Empire, vol. II: 1600-1914 (Cambridge: Cambridge University Press, 1994); Şevket Pamuk, Osmanlı İmparatorluğu’nda Paranın Tarihi (İstanbul: Tarih Vakfı Yayınları, 1999); Şevket Pamuk, A Monetary History of the Ottoman Empire (Cambridge: Cambridge University Press, 2000); 
yürütülen arkeolojik kazılarda bulunan Beçin Definesi 16. yy. ve 17. yy. başı para tarihi ile ilgili bilgilerin maddi kanıtlarla yeniden gözden geçirilmesine olanak sağlamıştır. ${ }^{3}$ Definede 48.849 İslami sikke belirlenmiştir. Bunların büyük bir kısmı Osmanlı akçesidir. Kırım Hanları ile Safevilere ait az sayıda sikke ile birlikte 842 Avrupa sikkesi de definede yer almaktadır. Osmanlı sikkelerinin büyük bir çoğunluğu, 3.898 akçe ile III. Murad (1574-1595), 31.625 akçe ile III. Mehmed (1595-1603) ve 6.716 akçe ile I. Ahmed (1603-1617) dönemine aittir. Numizmatik verilerin Osmanlı belgelerindeki kayıtlar ve arkeometri araştırmaları ile desteklenmesi sonucu ulaşılan yeni bilgiler Osmanlı para tarihine yeni bir bakış açısı kazandırmıştır. ${ }^{4}$ Numizmatik verileri değerlendirmek için para tarihindeki gelişmelere gözatmakta yarar vardır.

Şevket Pamuk "The Ottoman Monetary System and Frontier Territories in Europe, 15001700", International Journal of Turkish Studies 9 (2003), s. 175-82; Şevket Pamuk, "Prices in the Ottoman Empire, 1469-1914", International Journal of Middle East Studies 36 (2004), s. 451-468; Baki Tezcan, "The Ottoman Monetary Crisis of 1585 Revisited", Journal of the Economic and Social History of the Orient, 52 (2009), 460-504; Cemal Kafadar, "Prelude to Ottoman Decline Consciousness: Monetary Turbulence at the End of the Sixteenth Century and the Intellectual Response", Osmanl Araştırmalar Dergisi, 51 (2018), 265-295'de, aşağıdaki yayınlarda yer alan güncel bilgiler, tartışmalar bulunmamaktadır ve "Les troubles monétaires de la fin du XVIeme siecle et la prise de conscience ottomane du déclin", Annales. Économies, Sociétés, Civilisations. 46e année, 2 (1991), 381-400'de yayınladığı Fransızca makalesini İngilizce olarak biraz genişleterek tekrar yayınlamıştır. Her iki çalışma da yazarın doktora çalışmasına dayanmaktadır, bkz. Cemal Kafadar, "When Coins Turned into Drops of Dew Bankers Became Robbers of Shadows. The Boundaries of Ottoman Economic Imagination at the End of the Sixteenth Century", (doktora tezi) McGill University, 1986.

3 Ayrıntılı bilgi için Der Münzschatz von Beçin, I-II, ed. Rahmi Hüseyin Ünal, Fritz Krinzinger, Michael Alram, Şule Pfeiffer-Taş (Wien: Verlag der Österreichischen Akademie der Wissenschaften, 2010); Beçin Definesi, I-II, ed. Rahmi Hüseyin Ünal, Fritz Krinzinger, Michael Alram, Şule Pfeiffer-Taş (Ankara: Türkiye Bilimler Akademisi, 2015).

4 Şule Pfeiffer-Taş, "Zur Geldgeschichte im Osmanischen Reich in der Zeit von Selim I. bis Ahmed I.”, Der Münzschatz von Beçin, I, s. 70-116; Nikolaus Schindel ve Şule Pfeiffer-Taş, "Numismatischer Teil -Murad III. bis Ahmed I.", Der Münzschatz von Beçin, I, s. 134-389; Aydoğan Demir, Teoman Gültekin, Çakmak Şakir, "Numismatischer Teil (Selim I.-Selim II.)", Der Münzschatz von Beçin, I, s. 129-133; Martha Rodrigues ve Manfred Schreiner, "Non-Destructive Analysis of the Hoard of Beçin", Der Münzschatz von Beçin, I, s. 526-538. Almanca yayınların Türkçesi için bkz. Beçin Definesi; Aydoğan Demir, Teoman Gültekin, Çakmak Şakir, "Numizmatik - I. Selim’den II. Selim’e Kadarki Dönem”, Beçin Definesi, I, s. 121-124; Şule Pfeiffer-Taş, "I. Selim'den I. Ahmed'e Kadarki Dönemde Osmanlı Devletinin Para Tarihi”, Beçin Definesi, I, s. 65-108; Nikolaus Schindel ve Şule Pfeiffer-Taş, 
Osmanlı akçesinin darbında vezin belirlenmesinde bir dirhem metrolojik referans olarak alınmaktaydı. 1 dirhemin ağırlığı ise, coğrafi farklılıklar göstermektedir. Osmanlı akçesi darbı için, 3.072 gr ağırlığındaki Tebriz dirhemi kullanılmıştır. ${ }^{5}$ Akçenin içindeki gümüş oranını belirleyen ayarın ise resmî olarak \% 98-\% 99 olarak tespit edildiği aşağıda aktarılacağı üzere yazılı belgelerle kanıtlanmaktadır.

I. Süleyman zamanında Novaberde ve Kretova darphanelerindeki maden ocağı kadılarına gönderilen 943/1536-37 tarihli Maden Ocağ tekrar teyit edilmektedir; buna göre 100 dirhem akçe eritildiğinde, geriye 98 veya 99 dirhem gümüş kalırsa bunlar, çok iyi akçeler olarak adlandırılmaktadır. Eğer 95 veya 96 dirhem kalırsa bu, akçelerin kem ayar darp edildiği anlamına gelmekteydi. ${ }^{6}$ Kanuni'den çok daha önce de, Osmanlı devletinin en karışık dönemi olan Fetret Devri'nde bile aynı kuralın geçerli olduğu Emir Süleyman’in akçeleri üzerinde yapılan arkeometrik analizler sonucu ortaya çıkmıştır. Emir Süleyman'ın resmî olarak bastırdığı ilk akçelerindeki gümüş oranı \% 98 civarındadır; ancak daha sonraki dönemlerde taht mücadelesi sırasında bastırdığı sikkelerde bu oranın düştüğü görülmektedir. ${ }^{7}$ Osmanlı devletinin en zor dönemlerinden biri olan 16. yy.'ın ikinci yarısında da bu kurallara özen gösterildiği arkeometri analizleri ile kanıtlanmıştır.

"Numizmatik - III. Murad'dan I. Ahmed'e", Beçin Definesi, I, s. 125-378; bu makalede, tekrar olmaması için yalnızca yayının ilk versiyonu olan Almancaya atıfta bulunulacaktır ve orada verilen kaynakça ve açıklamalar gerekmedikçe tekrar verilmeyecektir. Türkçe için bkz. ilgili bölümler; sonuçlar için ayrıca bkz. Pfeiffer-Taş ve Schindel, ”The Beçin Coin Hoard and Ottoman Monetary History", s. 653-671.

5 Sahillioğlu, "Osmanlı Para Tarihinde", s. 14; Halil İnalcık, "Introduction to Ottoman Metrology”, Turcica, 15 (1983), s. 311-348, Pfeiffer-Taş, "Zur Geldgeschichte im Osmanischen Reich", s. 70-116; Şule Pfeiffer-Taş, "New Remarks Regarding Ottoman Monetary History in Light of the Akçe-Coins of Murad III.", Bildiriler-Proceedings /Birinci Uluslararası Anadolu Para Taribi ve Numismatik Kongresi, 25-28 Şubat 2013-First International Congress of the Anatolian Monetary History and Numismatics, 25-28 February 2013, ed. Kayhan Dörtlük, Oğuz Tekin, Remziye Boyraz Seyhan (Antalya: AKMED, 2014), s. 489-507.

6 Ahmed Akgündüz, Osmanlı Kanunnâmeleri ve Hukukî Tablilleri, V/2: Kanunî Devri Kanunnâmeleri (İstanbul: Fey Vakfı, 1992), s. 297; Pfeiffer-Taş, "Zur Geldgeschichte im Osmanischen Reich", s. 71.

7 Şule Pfeiffer-Taş, "The Coin Hoard of Ottoman Emir Süleyman in Tire Museum”, Proceedings of the 14th International Congress of Turkish Art, Collège de France, Paris, 19-21 September 2011, (Paris, 2013), s. 627-641. 
I. Selim'in tahta çıkısından hemen önce (1512 ) 100 dirhem gümüşten 400 akçe darp edildiği belgelenmiştir. ${ }^{8}$ Bir akçe ağıllığını 0.768 gram $^{9}$ olarak belirleyen bu sikke veznine 921/1516 tarihinde de uyulmuştur. ${ }^{10}$

Akçe vezni 1536 ve 1548 yıllarında I. Süleyman tarafından kanuna bağlanmıştır. Buna göre 100 dirhem gümüşten 420 akçe darp edilmesi gerekmekteydi. ${ }^{11}$ 421 veya 419 akçe kabul edilebilir sayılmaktayd. ${ }^{12}$

13 Safer 980/26.6.1572 tarihli bir belgeye göre, II. Selim’in son döneminde 100 dirhemden 450 akçe kesilmiştir. ${ }^{13}$ Bu veznin kullanımına ilişkin şimdiye

8 Mustafa Akdağ, "Osmanlı İmparatorluğu’nun Kuruluş ve İnkişafı Devrinde Türkiye'nin İktisadi Vaziyeti”, Belleten, 13 (1949), s. 497-571, s. 518, Kayseri Şeriyye Sicilleri'nden 916-917 tarihli defter, Tereke 917’yi zikretmektedir.

9 I. Selim'in bilinen akçelerinin arasında, 918 tarihli, 0,765 gram ağılıklı Amasya darplı ve Novar darplı 0,750 gramlık akçeler de bulunmaktadır; Slobodan Srećković, Akches, Volume Two. Mehmed II Fatih-Selim I Yavuz, 848-926 AH (Belgrade: S. Srećković, 2000), s. 156, no: 48 , s. 153 no: 37.

10 Akdağ, “Osmanlı İmparatorluğu’nun Kuruluş ve İnkişafı Devrinde”, s. 518'de Bursa ve Karesi sancaklarına gönderilen ve bu sikke veznini emreden fermanlardan alıntılar yapmaktadır.

11 Akgündüz, Kanunî Devri Kanunnâmeleri, s. 297 madde 6 ve 7; Pfeiffer-Taş, "Zur Geldgeschichte im Osmanischen Reich”, s. 71. Halil Sahillioğlu yayınlanmamış olan doktora tezinde, I. Süleyman'ın hükümdarlığı sırasında, 100 dirhemden 420 akçe darp edildiğine işaret etmektedir. Halil Sahillioğlu, "Kuruluşundan XVIII. Asrın Sonlarına Kadar Osmanlı Para Tarihi Üzerinde Bir Deneme" (doktora tezi), İstanbul Üniversitesi, 1958, s. 64-74, dipnot 7. Daha sonraki çalışmalarında, yayınlanmamış doçentlik tezinde ve daha yeni tarihli bazı eserlerinde, bu görüşünü düzeltmekte ve 973//1565’ de 100 dirhemden 450 akçe basıldığını söylemektedir. Ancak bu görüş için kaynak göstermemektedir. Halil Sahillioğlu, "Bir Asırlık Para Tarihi (1640-1740)" (doçentlik tezi), İstanbul Üniversitesi İktisat Fakültesi, 1965, s. 5 ile Halil Sahillioğlu, "The Role of International Monetary and Metal Movements in Ottoman Monetary History 1300-1750", Halil Sahillioğlu, Studies on Ottoman Economic and Social History (İstanbul: IRCICA, 1999), s. 27-64, s. 63, tab. 8, bununla birlikte, tespitleri daha sonraki pek çok yayında kullanılmıştır. Barkan, 'Onalıncı Asrın İkinci Yarısında Türkiye'de Fiyat Hareketleri', s. 572; Nezihi Aykut, 'Osmanlı İmparatorluğu’nda XVII. Asır Ortalarına Kadar Yapılan Sikke Tashihleri', Prof. Dr. Bekir Kütükoğlu’na Armağan (İstanbul: Edebiyat Fakültesi Basımevi, 1991), s. 343-360, s. 347; Mübahat Kütükoğlu, “1009 (1600) Tarihli Narh Defterine Göre İstanbul'da Çeşitli Eşya ve Hizmet Fiyatları”, İ. U. Ed. Fak. Tarih Enstitüsü Dergisi, 9 (1978), s. 5; Pamuk, Paranın Taribi, s. 63 ve 68, tab. 4.1 .

12 Akgündüz, Kanunî Devri Kanunnâmeleri, s. 297.

13 Sahillioğlu, "Kuruluşundan XVIII. Asrın Sonlarına Kadar Osmanlı Para Tarihi”, s. 64-74. 7 nolu dipnot BOA, Kamil Kepeci (KK.d), nr. 67, vr. 91b’ yi zikretmektedir. 
kadar bize ulaşan en erken bilgi, bu belgededir. Erzurum beğlerbeğine ve kadısına verilen bir emirde, 19 Cemaziyülevvel 982/06.9.1574 tarihinde 100 dirhemden yasalara aykırı biçimde 450 'den fazla akçe darp edildiğinin bildirilmesi ${ }^{14}$ bu tarihte sikke vezninin hâlâ 100 'e 450 ve her bir akçe ağırlığının 0.68 gram olduğunu belgelemektedir.

Osmanlı ekonomi ve para tarihinde, III. Murad dönemi (1574-1595), çok büyük fiyat artışları olması ve akçenin değerinin düşürülmesi nedeniyle oldukça karmaşık bir dönemdir. III. Murad tahta geçtiği zaman, akçenin vezni ile ilgili elimizde yazılı bir belge bulunmamaktadır; ancak genel olarak ağırlığının 0,68 gr. olduğu kabul görmüştür. ${ }^{15}$

Bu bağlamda, dönemin aydın ve özellikle malî konularda üst düzey bürokratı Mustâfâ Selânikî nin ${ }^{16}$ verdiği bilgilere göz atmakta fayda vardır; 4 Cemaziyülahir $997^{17} / 20$ Nisan 1589 tarihinde Erzurum'da seferde iken Beylerbeyi Vakası ile bağlantılı olarak gelen mektup ve haberleri aktarmaktadır. Aktarımda bölük halkının çoğunun Gence seferinden dönünce "alel-ittifak hurda akçe"18 olarak tanımladığ akçeden şikayetlerini bildirmektedir. Bu bilgi, aşağıda görüleceği üzere Gence darphanesinin de Doğu grubu hafif vezin kullanması açısından özel bir önem taşımaktadır. Selânikî, anlatımında, "100 dirhem gümüşten 500 akçe kesilmek kanun-ı padişahi iken, 100 dirhem gümüş 2000 adet zuyuf akçe olub hiç bir vecible amele yaramayub...” diye yazmaktadır. ${ }^{19}$ Bu vezin, yine dönemin aydın ve yüksek

14 BOA, Mühimme Defterleri (A.DVNS.MHM.d), nr. 26, s. 549.

15 Tartışma için bkz. Pfeiffer-Taş, "New Remarks Regarding Ottoman Monetary History", s. 489-507.

16 Mustafa Selanikî (ö. 1600 civarı) ve eseri için bkz. Selânikî Mustafa Efendi, Tarih-i Selânikî,, I-II, haz. Mehmet İpşirli (İstanbul: İstanbul Üniversitesi Edebiyat Fakültesi Yayınları, 1989); Şule Pfeiffer-Taş, "Inhaltsangabe der Chronik Selanikis und Vergleich mit dem Werk Naimas (April 1594-Jaenner 1597)” (doktora tezi), Universität Wien, 1993, buralarda verilen kaynakça.

17 Bu tarih, Selânikînnin; Erzurum'da seferde olmasından dolayı İstanbul'da bulunmadığı için, kendisine bilginin ulaştı̆̆ı tarihtir; Tarih-i Selânikî, I, s. 209-211; krş. Pfeiffer-Taş, "Zur Geldgeschichte im Osmanischen Reich", s. 79; Pfeiffer-Taş, "New Remarks Regarding Ottoman Monetary History", s. 489-507.

18 Tarih-i Selânikî, I, s. 210.

19 Tarih-i Selânikî, I, s. 210. Tartışma ve karşılaştırmalar için Pfeiffer-Taş, "Zur Geldgeschichte im Osmanischen Reich", s. 79; Pfeiffer-Taş, "New Remarks Regarding Ottoman Monetary History", s. 489-507. Bu bilgi için ayrıca bkz. Halil İnalcık, "İki Rakip Kardeş: Altın ve Gümüş. Two Rivals: Gold and Silver”, Altının İktidarı, İktidarın Altınları. Yapı Kredi Para 
düzey başka bir bürokratı olan Âli'de de yer almaktadır. ${ }^{20}$ Bu durumda, büyük vezin değişikliğinin uygulandığı 1588 öncesinde 0,614 gr. ağırlığında bir veznin olması sözkonusudur. ${ }^{21}$ Selânikî ayrıca, 1 dirhem gümüşün 12 akçeye alınıp satıldığını bildirmektedir. ${ }^{22} 1589$ yılında yapılan bu bildirim, hafif vezin kullanımı açısından dikkat çekicidir.

Tam olarak ne zaman olduğu bilinmeyen, genelde 1582-86 yılları arasında yapıldığı öngörülen, ancak son araştırmalarda 1588 civarına tarihlenen ${ }^{23}$ tash $_{\text {ih }}-i$ sikke $e^{24}$ uygulamasından sonra, Osmanî akçenin vezni 0.38 grama düşürülmüştür; yani 100 dirhem gümüşten 800 akçe darpedilmiştir. Akçe veznindeki bu büyük değişiklik, ekonomi tarihi konusunda yapılan araştırmalarda, çoğunlukla akçedeki gümüş oranının düşürüldüğü şeklinde yorumlanmış ve tağşiş politikası uygulandığı ifade edilmiştir. Ancak, numizmatik bilimi açısından tağşiş, Arapça غش kelimesi ile bağlantılı olarak aldatma, hilekarlık, sabtekarlık, içine başka madde karıştırma $v b .{ }^{25}$ anlamlarıyla ele alınmaktadır. Literatürde yer alan 1585-1586'daki

Koleksiyonu Altın Sikke Sergisi - Power of Gold, Golds of Power, Exhibition of Gold Coins Yapı Kredi Collection 10.9.2004 - 26.2.2005, ed. Oğuz Tekin (İstanbul: Yapı Kredi Yayınları, 2004), s. 148.

20 Sahillioğlu, "Kuruluşundan XVIII. Asrın Sonlarına Kadar Osmanlı Para Tarihi”, s. 221'de Âli'nin el yazmasını referans vermektedir: Nasihatül Mülûk, Fatih Kütüphanesi, Yazma 3522, vr. 88a: "Kanun-i kadimde yüz dirhem gümüşten 500 dirhem (akçeyi kasdediliyor) kesildü̈̆i." Ayrıca bkz. Joseph von Hammer-Purgstall, Geschichte des Osmanischen Reiches, IV (Graz: Akad. Dr.-u. Verl.-Anstalt, 1963) [Tipkıbasım], s. 193; İbrahim Artuk ve Cevriye Artuk, İstanbul Arkeoloji Müzeleri Teşhirdeki İslâmi Sikkeler Kataloğu, II (İstanbul: T.C. Başbakanlık Kültür Müsteşarlığı, 1974), s. 557; Andreas Tietze, Muștafā 'Āli's Counsel for Sultans of 1581, I-II (Wien: Verlag der Österreichischen Akademie der Wissenschaften, 1979-1982), I, s. 184; bu yayında, "how many hunderts" olarak tercüme edilmiştir.

21 Pfeiffer-Taş, "New Remarks Regarding Ottoman Monetary History”, s. 489-507.

22 Bilginin bütün nüshalarındaki karşılaştırma için bkz. Tarih-i Selânikî, I, s. 210.

23 Hurda/küçük olarak adlandırılan akçelerin, Haziran 1588'de darp edilmeye başlandığı ve en geç 15 Şevval 966/7 Eylül 1588'de kullanımda oldukları düşünülmektedir. Tırhala Sancakbeği, İstanbul'a yazdığı bir yazıda, muhtemelen bu akçelerle ücretlerini alan askerlerin, bununla ödeme yapamadıklarını, zira halkın "hurda" olarak adlandırdıkları bu sikkeleri almayı reddettiğini bildirmiştir. Ayrıntılı bilgi için Pfeiffer-Taş, "Zur Geldgeschichte im Osmanischen Reich”, s. 70-116 ve burada verilen kaynakçaya bakınız.

24 Aykut, "XVII. Asır Ortalarına Kadar Yapılan Sikke Tashihleri” ve buradaki kaynakçaya bakınız.

25 Julius Theodor Zenker, Türkisch-Arabisch-Persisches Handwörterbuch, I-II (Hildesheim-New York: Georg Olms Verlag, 1979), s. 648; tağşşs kelimesi s. 295'de "action de tromper, action 
tăģşş̧-i sikke $e^{26}$ olarak adlandırılan değişiklik sırasında, numizmatik açıdan akçelerin gümüş oranında tağşiş yapılmadığı son araştırmalarda ortaya konmuştur; bu değişiklik sırasında yalnızca vezninin düşürüldüğü tespit edilmiştir. Bu tespit, aynı döneme ait çok sayıda akçe üzerinde darp tekniği, stil özellikleri, vb. incelenmesi ile yapılabilmiştir. Sözkonusu tespit, ayrıntılı bir analiz olanağı sunan Beçin definesindeki III. Murad (1574-1595), III. Mehmed (1595-1603) ve I. Ahmed (1603-1617) dönemine ait sikkeleri kapsamaktadır; yapılan arkeometrik araştırmalarda 392 aded akçenin gümüş oranı oldukça yüksek çıkmıştır. ${ }^{27}$ III. Murad döneminde akçelerin büyük bir kısmının gümüş oranının \% 95ler ve üzeri olduğu, III. Mehmed ve I. Ahmed döneminde \%98-\%99’lara ulaştığı ve her üç sultana ait 392 akçeden 237 adedinin gümüş oranının \%94-\%97 arasında olduğu kanıtlanmıştır. ${ }^{28}$ Numizmatik araştırmalar ile birlikte akçelerin gümüş oranı üzerine yapılan bu çalışma sözkonusu dönem için ilk ayrıntılı araştırmadır. ${ }^{29}$ Akçeler içinde 1153 kalıpları üzerinde oynanmış ve 301 üzeri gümüş kaplama kalp akçe vardır, ki bunlar ayrı olarak değerlendirilmiştir. ${ }^{30}$

de falsifier, d'altérer par un mouvais mélange/ Täuschung, Falscheit; Fälschung, Verfälschung, tă̆şsis-i maden, Fälschung der Metalle” olarak verilmiştir. Sir James Redhouse, Yeni Türkçe-İngilizce Sözlük / New Redhouse Turkish-English Dictionary (İstanbul: Redhouse Yayınevi, 1983), s. 1078, tağşsis için "an adulterating, adulteration, a falsifying" anlamlarını vermektedir.

26 Pamuk, Paranın Tarihi, s. 132, 135, 139, 140, 143-148 ve buralarda verilen kaynakçaya bakınız.

27 Pfeiffer-Taş ve Schindel, “The Beçin Coin Hoard and Ottoman Monetary History”, s. 665; $\mathrm{Bu}$ araştırmada kullanılan metot ve ayrıntılar için Martha Rodrigues ve Manfred Schreiner, "Non-Destructive Analysis of the Hoard of Beçin", Der Münzschatz von Beçin, I, s. 526-538.

28 Schindel ve Pfeiffer-Taş, "Numismatischer Teil”, s. 377, tab. II.258, s. 378; tab. II.261; Pfeiffer-Taş ve Schindel, "The Beçin Coin Hoard and Ottoman Monetary History”, s. 664; 665; Schindel ve Pfeiffer-Taş, "Murad III. bis Ahmed I.”, s. 377 v.d.

29 III. Murad akçeleri üzerinde daha önce yapılan tek arkeometrik araştırma, yalnızca 1 adet akçe üzerindedir. $\mathrm{Bu}$ akçenin gümüş oranı $\% 79$ olarak belirlenmiş ve yalnızca ağırlığın değil great debasement/büyük tağşiş uygulanarak akçelerin gümüş oranının da düşürüldüğü varsayılmıştır; Walter Hüsch v. dğr., "The Fineness of Ottoman Akces”, Oriental Numismatic Society Newsletter, 155 (1998), s. 12, tab. 2. Ancak, numizmatik verileri kesin olmayan tek bir sikke üzerinden böyle bir sonuca varmak yöntem olarak olanaksızdır. III. Mehmed'e ait bir akçe üzerinde yapılan analizin sonucu ise $\% 95$ çıkmışıิır ve Beçin Definesi analizleri ile uyuşmaktadır; Necdet Kabaklarlı, Metin Erüreten, “Osmanlı Paralarında Ölçü ve Ayar / The Unit of Measurement and Scales of Ottoman Coins" Necdet Kabaklarli, Mangir: Tire'de Darpedilen Osmanlı Bakır Paralar//Ottoman Copper Coins Minted in Tira, 14111516 (İstanbul: Uşak Belediyesi Kültür Hizmeti, 2007), s. 128-136 (EK 2/ Appendix II).

30 Pfeiffer-Taş ve Schindel, “The Beçin Coin Hoard and Ottoman Monetary History”, s. 666. 
III. Murad-I. Ahmed dönemi arasında Osmanlı akçelerinin ağırlıklarının çok iyi kontrol edildiği, Osmanlı darphanelerinin hem teknik hem de idari açıdan son derece düzenli çalıştığı görülmektedir. Osmanlı arşiv belgelerinden elde edilen veriler numizmatik araştırmaların sonuçlarıyla örtüşmektedir ki buna en iyi örnekler arasında III. Mehmed döneminde Kostantiniye ve Ankara darphaneleri gösterilebilir. ${ }^{31}$

Beçin Definesi üzerinde yapılan araştırmalarda elde edilen en önemli sonuçlardan birisi, akçenin ağırlığı ile ilgili literatürde karşımıza çıkan bilgilere tamamen yeni bir açıklama getirmiş olmasıdır; araştırmalarda bu makalenin asıl konusunu oluşturan ve 16. yüzyılın sonlarında Osmanlı akçesinden daha düşük bir ağırlığa sahip kara(ca) akçenin varlığı ile ilgili önemli verilere ulaşılmıştır.

\section{I.2. İki Farklı Akçe Vezni ile İlgili Tespitler}

III. Murad ve III. Mehmed'e ait Osmanlı akçelerinde birbirinden stil, üzerindeki işaretler ve vezin açısından farklı iki grup tesbit edilmiştir. ${ }^{32} \mathrm{Bu}$ gruplar Stil A ve Stil B olarak adlandırılmıştır. Öncelikle Osmanlı akçesi olarak adlandırılan resmi vezni yansıtan B Stili grubunu incelemekte fayda vardır.

\section{B Stili Grubu}

B Stili grubundaki akçeler tamamen aynı özellikleri göstermektedir. Bu grupta, Kostantiniye'de darbedilen akçelerin kalıpları diğer darphanelere gönderilmekte ve buralarda aynı özelliklerde darp edilmektedir. Rumeli ve Anadolu stil grubu olarak adlandırdığımız bu grupta Osmanlıların Balkanlar, Batı Anadolu, KuzeyGüney hattı boyunca Ankara ve Konya'ya kadar uzanan bölge yer almaktadır. ${ }^{33}$ Stil B grubunda, III. Murad'ın 1588 civarındaki büyük devalüasyondan sonraki geç dönemine ait 2.818 adet akçenin ve III. Mehmed'in erken dönemine ait akçelerinin çoğunluğunun ağırlıklarının olması gereken 0,38 grama yoğunlaşması, ${ }^{34}$ uygulamadaki titizliği göstermektedir.

31 Pfeiffer-Taş, "Zur Geldgeschichte im Osmanischen Reich”, s. 70-116; Schindel ve Pfeiffer-

Taş, "Numismatischer Teil”, s. 226, tab. II.94 ve s. 223, tab. II.85. Pfeiffer-Taş ve Schindel,

"The Beçin Coin Hoard and Ottoman Monetary History", s. 656-657.

32 Schindel ve Pfeiffer-Taş, "Numismatischer Teil”, s. 158-162, 231-236, 309 vd., Pfeiffer-

Taş ve Schindel, "The Beçin Coin Hoard and Ottoman Monetary History”, s. 653-671.

33 Schindel ve Pfeiffer-Taş, "Numismatischer Teil”, s. 138. Pfeiffer-Taş ve Schindel, "The

Beçin Coin Hoard and Ottoman Monetary History", s. 658.

34 Schindel ve Pfeiffer-Taş, "Numismatischer Teil”, B.I, II.2. S. 156;158-162; 231-36; 309 v.d. 


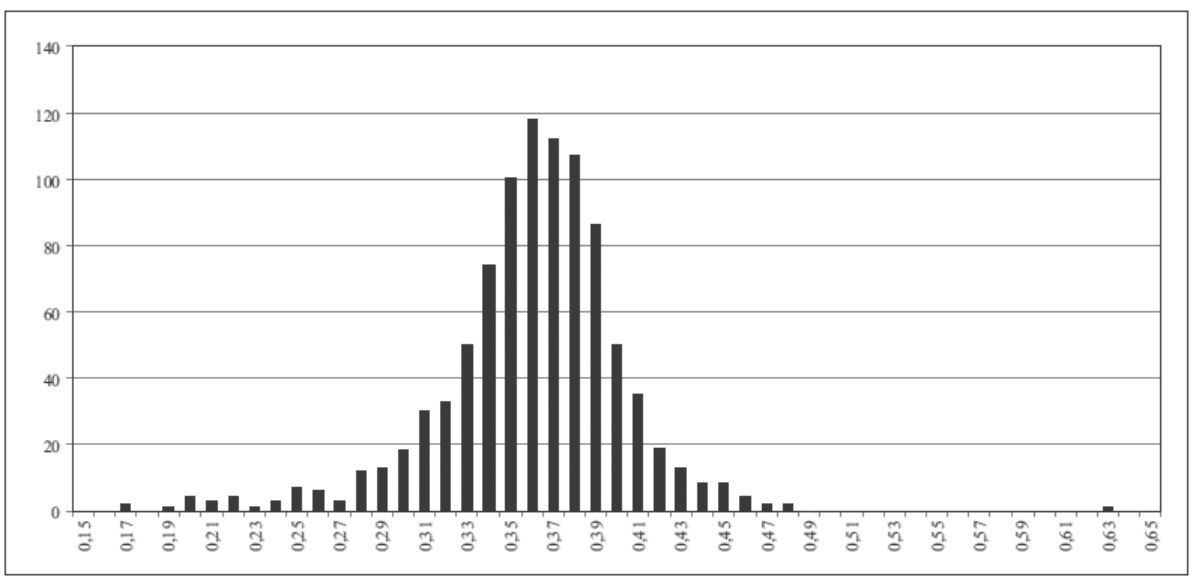

Grafik 1- III. Murad - Kostantiniye-B Stili (929 akçe) [Birim: 0,01 gr. $]^{35}$

III. Mehmed döneminde 1600 yılında 100 dirhem gümüşten 950 akçe kesilmesiyle 0,32 gr.olan resmi veznin ${ }^{36}$ uygulanması konusunda gösterilen titizliğin I. Ahmed döneminde de sürdürüldüğü görülmektedir. ${ }^{37}$

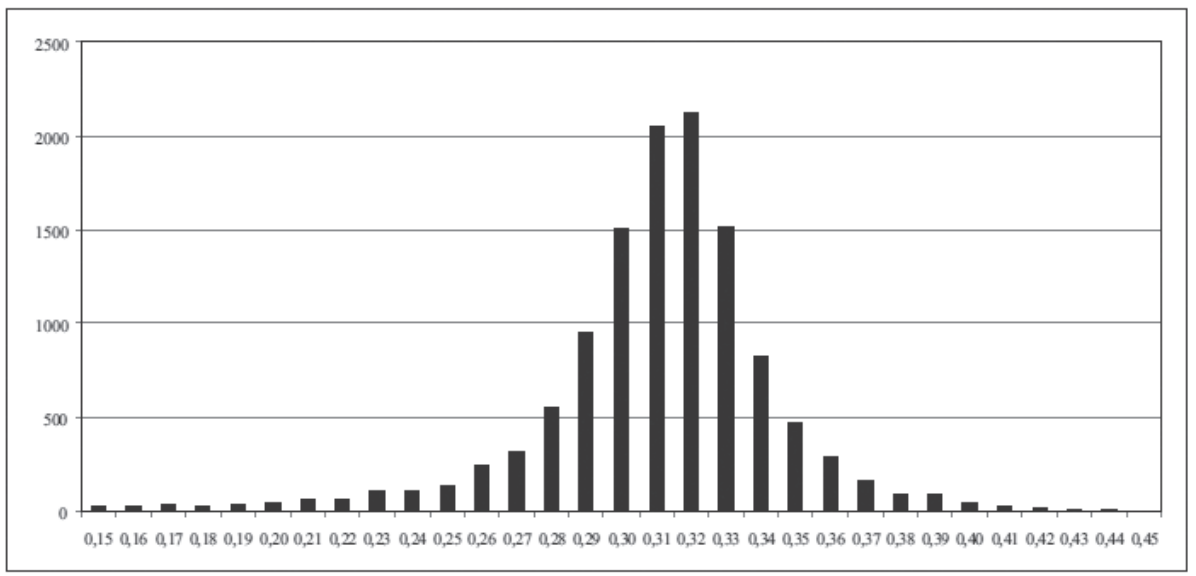

Grafik 2- III. Mehmed - Kostantiniye darphanesi (11.896 akçe) [Birim: 0,01 gr.] ${ }^{38}$

35 Schindel ve Pfeiffer-Taş, "Numismatischer Teil”, s. 157, tab. II.15.

36 Pamuk, Monetary History, s. 136, tab. 8.2; Schindel ve Pfeiffer-Taş, "Numismatischer Teil”,

s. 198-206; Pfeiffer-Taş, "Zur Geldgeschichte im Osmanischen Reich”, s. 84.

37 Schindel ve Pfeiffer-Taş, "Numismatischer Teil", s. 305-9.

38 Schindel ve Pfeiffer-Taş, "Numismatischer Teil”, s. 226, tab. II.94; Pfeiffer-Taş ve Schindel,

"The Beçin Coin Hoard and Ottoman Monetary History", s. 657. 
Aşağıdaki grafik, I. Ahmed dönemi akçe vezni olan 0,32 gr. ağırlığı belirgin bir şekilde yansıtmaktadır.

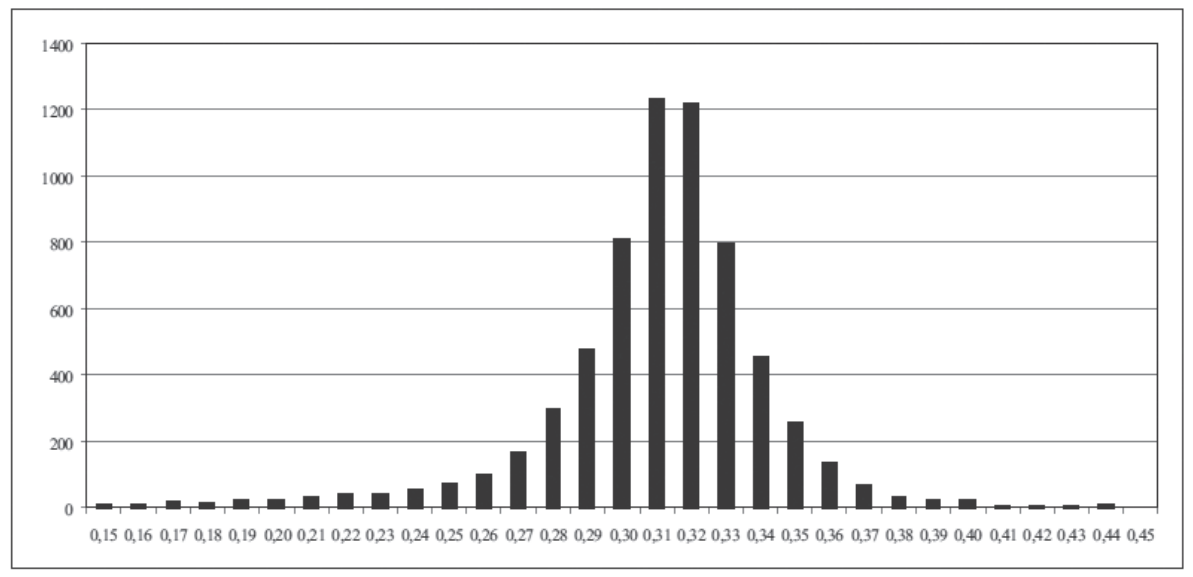

Grafik 3- I. Ahmed (6421 akçe) [Birim: 0,01 gr. ${ }^{39}$

I. Ahmed'in ölümünden sonra, 1618 'den itibaren ise 100 dirhemden 1000 akçe kesilmeye başlanmış ve akçenin resmi ağırlığı 0,31 gr. olmuştur; ki bu 0,01 gramlık fark da devletin vezne verdiği önemi göstermektedir.

\section{A Stili Grubu}

Stil A olarak adlandırılan gruba giren darphanelerin hepsi Doğu ve Güney Doğu Anadolu, Bilad-uş-Şam, Mısır ve Kafkaslar'da yer almaktadır. ${ }^{40}$ Numizmatik verilere göre değerlendirdiğimizde, III. Murad'ın son dönemi ve III. Mehmed'in 1600 yılına kadar olan erken dönemi akçelerinde (muhtemelen I. Ahmed akçelerinde de) bu gruba dahil olan Amid, Erzurum, Sivas, Van gibi darphanelerinin tipolojik olarak Anadolu ve Rumeli grubu olan B grubuna girenlerden tamamen farklı ve hepsinin kendine özgü özellikleri olduğu görülmektedir. Bu darphanelerde basılan akçelerin damgalarının yerel üretildiği gözlemlenmiştir. ${ }^{41}$

III. Murad'in geç dönemine ve III. Mehmed'in veznin 0,32 grama düştüğü 1600 yllından önceki erken dönemine ait sözkonusu Doğu darphanelerindeki en az

39 Schindel ve Pfeiffer Taş, "Numismatischer Teil”, s. 306; tab. II, 194.

40 Schindel ve Pfeiffer-Taş, "Numismatischer Teil”, s. 182-93; 269-84, 326-34; Pfeiffer-Taş ve Schindel, "The Beçin Coin Hoard and Ottoman Monetary History", s. 658.

41 Schindel ve Pfeiffer-Taş, "Numismatischer Teil”, s. 158-162, 231-236, 310; Pfeiffer-Taş ve Schindel, "The Beçin Coin Hoard and Ottoman Monetary History", s. 661. 
30 akçenin istatiksel olarak değerlendirilmesi sonucu A grubu vezninin 0,38 gr. yerine, belirgin olarak 0,30 gr. veya altında, 0,28 gr. civarında oldukları görülmüştür.

Bu grup içinde Amid özel bir konuma sahiptir. Kostantiniye'den sonra III. Murad akçeleri içinde definede en fazla akçe sayısı Amid darphanesindedir ve vezin, daha ağır akçeler bulunmasına rağmen 0,30 gr. altında yoğunlaşmaktadır. Bu durum, burada daha düşük bir vezin kullanıldığını düşündürmektedir.

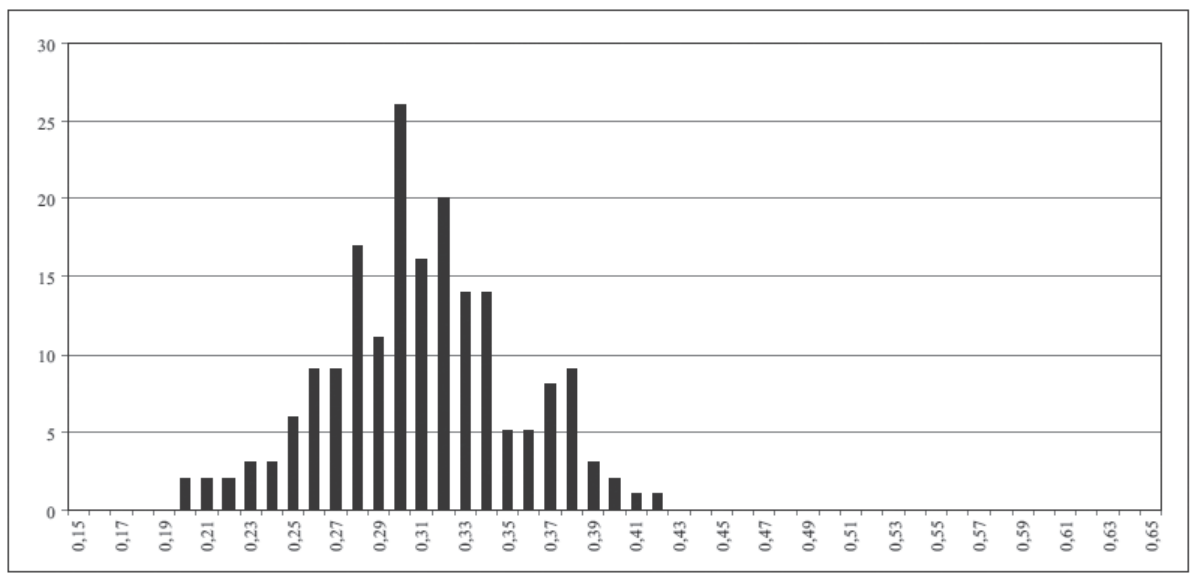

Grafik 4- III. Murad dönemi Amid (188 akçe) [Birim: 0,01 gr. ${ }^{42}$

III. Murad'ın Erzurum darplı akçelerinde de hafif vezin gözlemlenmektedir.

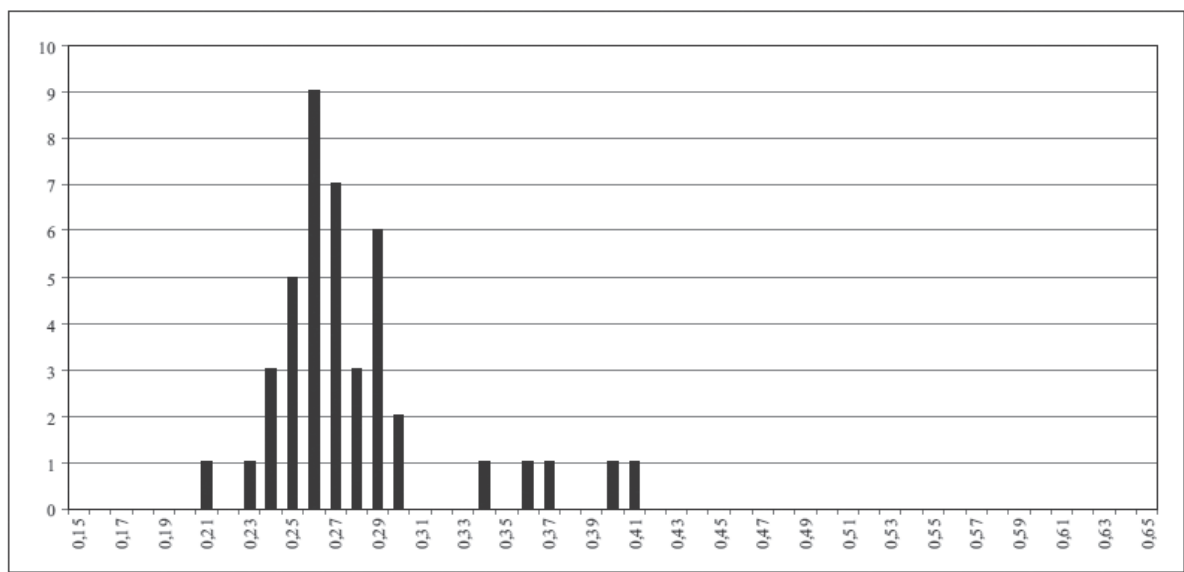

Grafik 5- III. Murad - Erzurum (42 akçe) [Birim: 0,01 gr. $]^{43}$

42 Schindel ve Pfeiffer-Taş, "Numismatischer Teil”, s. 159, tab. II.19.

43 Schindel ve Pfeiffer-Taş, "Numismatischer Teil", s. 160, tab. II.21. 
Gence darplı III. Murad'a ait üç akçe 0,22 gr., 0,28 gr. ve 0,29 gr. ağırllğındadır ve bu darphanenin de düşük vezin kullandığını düşündürmektedir, ancak bir sonuç çıkarmak için sayı yeterli değildir. ${ }^{44}$

Amid darplı III. Mehmed akçeleri de B grubundan tipolojik, stil ve metrolojik açıdan tamamen farklılık göstermektedir. Amid darplı akçelerde de yoğunluk hafif vezin olan 0,28 gr. civarında görülmektedir.

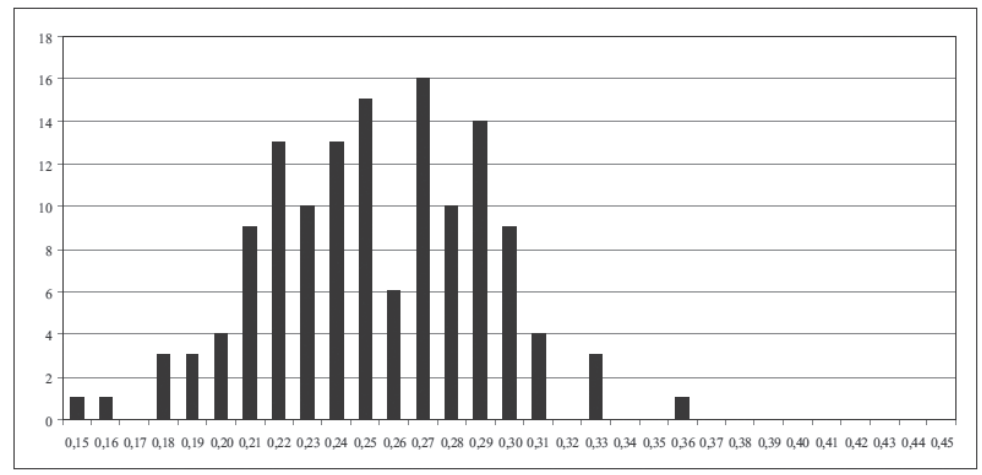

Grafik 6- III. Mehmed - Amid darphanesi (135 akçe $)^{45}$ [Birim: 0,01 gr.]

III. Mehmed'in A grubu darplı akçelerinde de Doğu grubu olarak adlandırdığımız düşük vezin kullanan darphaneler görülmektedir. Özellikle Van darplı akçeler belirgin bir şekilde 0,24 gr. da yoğunlaşmaktadır. Van darphanesinin Doğu veznini kullandığı stil ve tipolojik olarak da kendini göstermektedir.

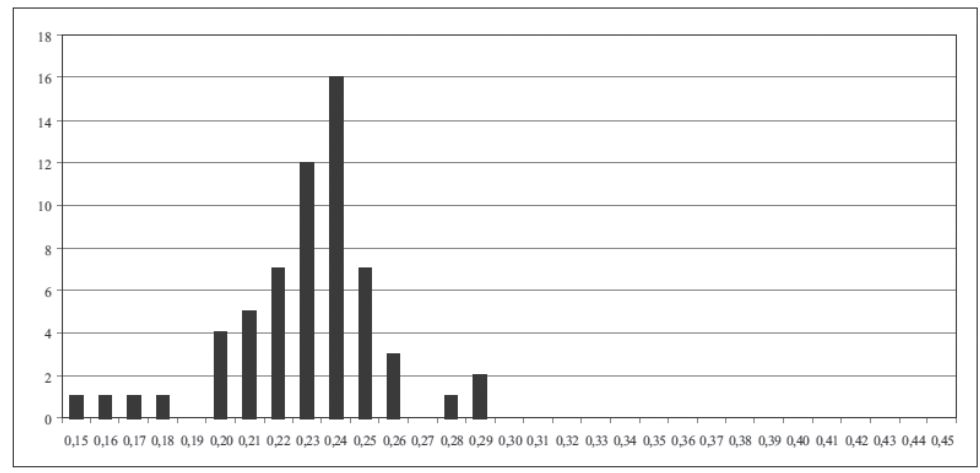

Grafik 7- III. Mehmed - Van darphanesi (61 adet) [Birim: 0,01 gr.] ${ }^{46}$

44 Schindel ve Pfeiffer-Taş, "Numismatischer Teil”, s. 160.

45 Schindel ve Pfeiffer-Taş, "Numismatischer Teil", s. 231, tab. II.106.

46 Schindel ve Pfeiffer-Taş, "Numismatischer Teil”, s. 236, tab. II.114. 
Gence, III. Mehmed'e ait 10 adet akçe ile yine Doğu veznini kullandığına işaret etmektedir. ${ }^{47}$

Erzurum, A grubuna giren sikkeler Canca ile büyük benzerlik göstermekte, ancak vezni daha düşüktür. ${ }^{48}$

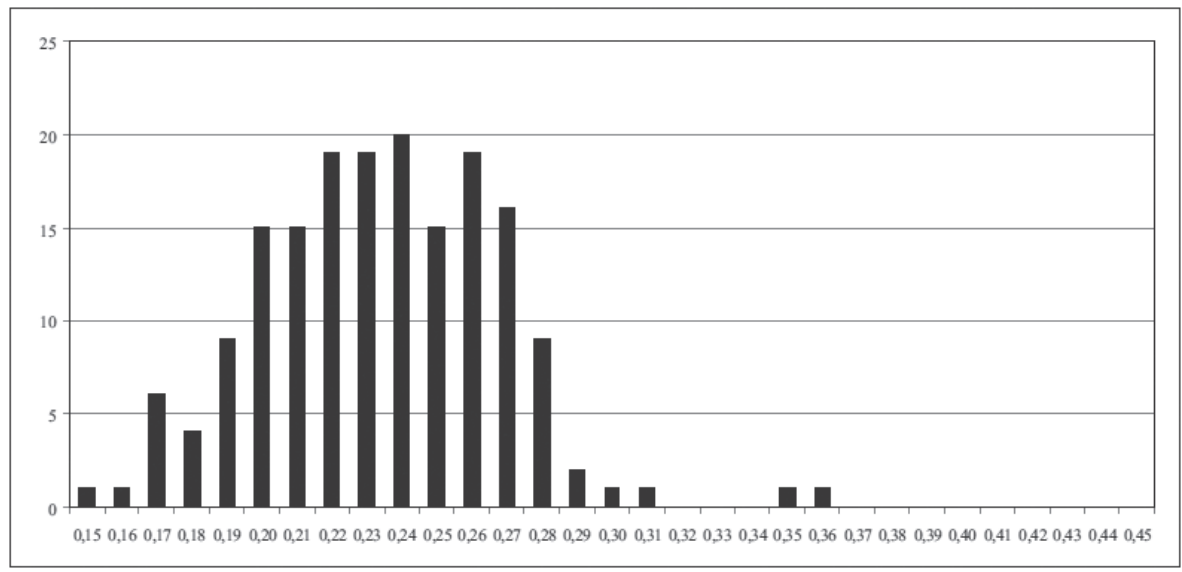

Grafik 8- III. Mehmed - Erzurum (174 akçe) [Birim: 0,01 gr. $]^{49}$

Canca, III. Murad ve III. Mehmed döneminin başlarında, Stil A olarak adlandırdığımız yerel Doğu veznini kullanmıştı, ${ }^{50}$ ancak III. Mehmed döneminde, tam belirleyemediğimiz bir tarihte, Stil B'yi oluşturan Rumeli ve Anadolu grubuna geçmiştir. ${ }^{51}$ Bu değişiklik merkezileşmeye işaret etmektedir. ${ }^{52}$

47 Schindel ve Pfeiffer-Taş, "Numismatischer Teil”, s. 233.

48 Tartışma için bkz. Schindel ve Pfeiffer-Taş, "Numismatischer Teil”, s. 233.

49 Schindel ve Pfeiffer-Taş, "Numismatischer Teil", s. 233, tab. II.108.

50 Erzurum Valisine ve Kadı'sına giden 19. Cemaziyülevvel 982//6.9.1574 tarihli bir fermandan anlaşıldığına göre, Canca darphanesi para basımında ayarına uymadığı için Erzurum'a nakledilmiştir. 100 dirhem gümüşden 450 akçeden fazla sikke darp edilmiş ve tüccar vasıtasıyla İran’a kaçırılmış olduğundan, piyasada para kalmamıştı. Erzurum Valisinin, Canca darphanesinin Erzurum'a nakli isteği de bu yazıyla kabul edilmiştir; BOA, Mühimme Defterleri (A.DVNS.MHM.d), nr. 26, s. 549; Pfeiffer-Taş, "Zur Geldgeschichte im Osmanischen Reich", s. 95-96.

51 Schindel ve Pfeiffer-Taş, "Numismatischer Teil”, s. 270-3. Pfeiffer-Taş ve Schindel, "The Beçin Coin Hoard and Ottoman Monetary History", s. 659.

52 Pfeiffer-Taş ve Schindel, "The Beçin Coin Hoard and Ottoman Monetary History”, s. 653-671. 


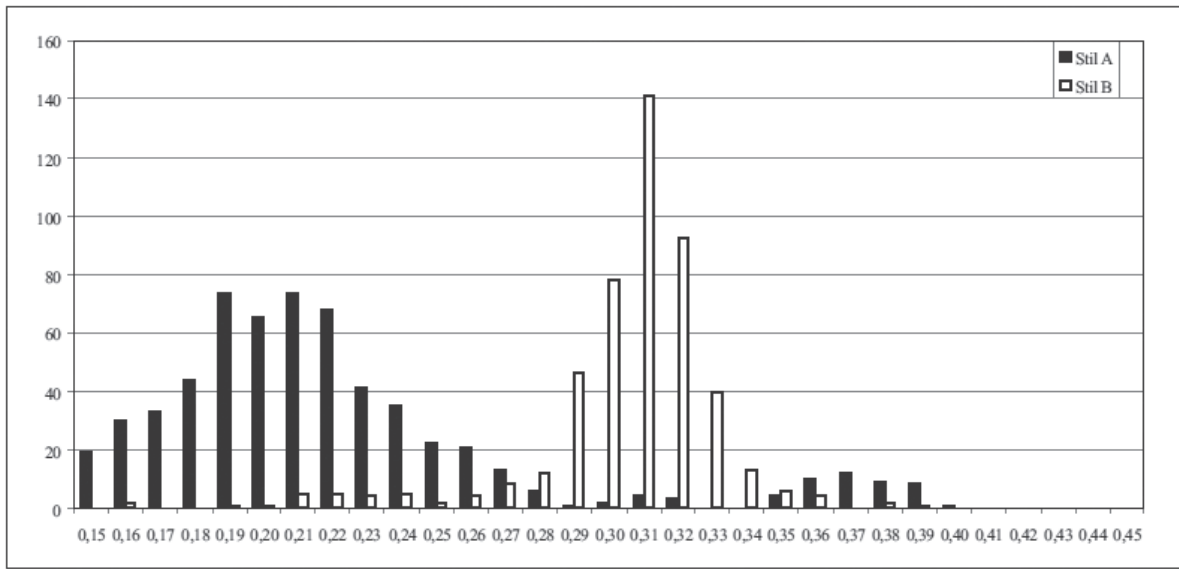

Grafik 9- Mehmed III - Canca darplı akçelerin ağırlıkları (1.069 akçe) [Birim: 0,01 gr. $]^{53}$

Bu tespit, bu makalenin asıl konusu olan, Osmanlıca belgelerde kara(ca) akçe olarak adlandırılan ve 16. yüzyıl sonlarında Doğu bölgesinde resmi olarak tedavülde olduğu anlaşılan para birimi ile ilişkilendirildiğinde daha da önem arz etmektedir. 62 nolu mühimme defterinde yer alan Şevval 995/Eylül 1587 tarihli bir kayıt, kara (ca) akçe darbı için resmi olarak izin verildiğini belgelemektedir. ${ }^{54} 16 . y y . d a n$ itibaren belgelerde karşımıza çıkan kara(ca) akçe para biriminin, Osmanî akçeden farklı, Doğu'da kullanılan bir para birimi olduğu kesinlik kazanmaktadır. Ayrıca bu sikkenin yalnızca bir muhasebe sikkesi olmadığı aynı zamanda darp edilmiş tedavülde bir akçe olduğu görülmektedir. Bundan sonraki kısımda belgelerde yer alan bu sikke ile ilgili bilgiler analiz edilecektir.

\section{Kara(ca) Akçe}

Kara(ca) akçe terimi ilk kez, Osmanlıların 1515 yılında Doğu ve Güneydoğu Anadolu bölgesinin fethinden sonra çıkarılan Diyarbekir Eyaleti Kanunnameleri'nin bazılarında geçmektedir. Yavuz Sultan Selim, 1453-1477 yılları arasında hüküm süren, Akkoyunlu hükümdarı Uzun Hasan'ın, bugünkü İran, Irak, Azerbaycan, Ermenistan ve Türkiye’nin bir bölümünü kapsayan ve Uzun Hasan Kanunları'nın geçerli olduğu Doğu ve Güneydoğu Anadolu’yu fethettiğinde bu bölgede, para, ölçü, tartı, örf ve adetlerine göre hazırlanan kanunların

53 Schindel ve Pfeiffer-Taş, "Numismatischer Teil", s. 232, tab. II.107.

54 BOA, Mühimme Defterleri (A.DVNS.MHM.d), nr. 62, s. 297/133. 
uygulamasını sürdürmüştür. ${ }^{55}$ Yavuz döneminde Diyarbakır Eyaleti’nin sancakları arasında yer alan Âmid Livası'nın 1518 tarihli ilk kanunu, „Hasan Padişah Kanuna” göre hazırlanan hukuki düzenlemede kara(ca) akçe olarak adlandırılan para biriminin karşılığı olarak Osmanî akçe değerleri de belirtilmiştir. Bu dönemde 1 Osmanî akçe 3 kara(ca) akçe değerindedir. Bu değer, kanunnamede geçen bütün kur hesaplamalarında tam olarak belirlenmiştir. Örneğin, çiftçilik ile ilgili düzenlemeye baktığımızda, her çift başına yetmiş iki karaca akçe resm-i çift alındığı, üçü bir Osmanî akçe hesabı üzere yirmi dört akçe olduğu, daha önce ilkbaharda nevruzda alındığı ve eskisi gibi olmasına karar verildiği belirtilmektedir. ${ }^{56}$ Yine, bir çeşit örfi vergi olarak kabul edilen, tavuk bedeli olarak her çift başına on karaca akçe alındığı, bunun üçü bir Osmanî hesabı üzere on akçe ve sülüs olduğu hesabı yazılmıştır. ${ }^{57}$ Ayrıca, resm-i 'alef yem vergisi için her çift başına yüz burma otluk alındığı, her yüz burmasının bahâsının otuzar karaca akçe olduğu ve üçü bir Osman akçesi üzerine on Osmanî olduğu, ${ }^{58}$ hayvanlardan alınan resm-i mevâş̧i için her inekten altı karaca akçe alındığı ki bunun üçü bir hesaba göre iki Osman akçesi ettiği ${ }^{59}$ köylerdeki sığır cinsiyle otlağa giden kuvvetli keçiden ve koyun

55 Ahmed Akgündüz, Osmanl Kanunnâmeleri ve Hukukî Tablilleri, III: Yavuz Sultan Selim Devri Kanunnâmeleri (İstanbul: Fey Vakfı, 1991), s. 217'de bu kanunmamelerde para birimleri, sıvı, ağırlık, alan ölçülerinin Akkoyunlular'a ve mahalli adetlere göre verildiğini, Karaca akçe, Hasanbeği, Eşrefî ve benzeri para birimlerinin Osmanlı akçeleri ile karşılıklarının verildiğini yazmaktadır.

56 "Evvel kurâda vâk' i olan réâyâdan anun kim, bir çiftlik zemini olub ve zirầatine kâdir olsa, her çift başına yetmiş iki karaca akçe resm-i çift alınur imiş ki, üçü bir Osmanî akçe hesabı üzere yiğirmi dört akçe olurmuş. Re’âyadan alınmasının dahi mevsimi, evvel bahar nevrûzda imiş, hem evvel üzere mukarrer alınd”", Akgündüz, Yavuz Sultan Selim Devri Kanunnâmeleri, s. 221 , madde 1 .

57 "Ve deh-nîm diyü mâkyân-bahâ her çift başına on karaca akçe dahi alınur imiş ki, üçü bir Osmanı̂ hesâbı üzere on akçe ve sülüs olur imiş. Bunun dahi alınmasının mevsimi nevrûzda imiş", Akgündüz, Yavuz Sultan Selim Devri Kanunnâmeleri, s. 221, madde 2; dipnot 2'de deh-nîm= yirmide bir ve mâkyân-baha= tavuk bedeli; bir örfi vergi konusunda açıklamalar verilmiştir.

58 "Ve resm-i 'alef her çift başına yüz burma otluk dabi alınurimiş ki, her yüz burmasının bahâsı otuzar karaca akçe imiş. Üçü bir Osman akçesi hesâbı üzere on Osmanî olur”, Akgündüz, Yavuz Sultan Selim Devri Kanunnâmeleri, s. 221, madde 5; dipnot 5'te burma = bir büklüm ot olarak açıklanmıştır.

59 "Ve resm-i mevâş̧ her inekden altı karaca akçe alınur imiş ki, üçü bir hesaba üzere iki Osman akçesi olur. Ve ehl-i kuâda olan sı̆̆ır cinsiyle otlăga giden azrağu keçiden ve koyun cinsinden üçer karaca akçe alınur imiş ki, bir Osman akçesi olur. Anun alınması ref' olub defter-i cedîde hâsıl kayd olmadi", Akgündüz, Yavuz Sultan Selim Devri Kanunnâmeleri, s. 221, madde 7. 
cinsinden üçer karaca akçe alındığı ki bunun da bir Osman akçesi olduğu, ancak alınması ref olduğundan yeni deftere hasıl kayıt olmadığı yazılmıştır. Bu kanunun diğer maddelerinde de çeşitli vergilendirmeler konusunda kararlar yazılmış olup hepsinde de $3=1$ hesabı belirtilmiştir. ${ }^{60}$

Ergani de kara(ca) akçenin yoğun olarak kullanıldığ Mardin ve Siverek sancağında da yine özellikle transit ticaret için birçok vergi hesaplamasında kara(ca) akçe olarak verilen rakamlar Osmanî olarak da hesaplanırken aynı rakamlar kullanılmıştır. ${ }^{62}$ Burada görüldüğü gibi, hesap tam olarak 1 Osmanî akçe karşılığ1 3 karaca akçe olarak yapılmış, bu örnekte olduğu gibi her meblağın karşılığı karaca akçe ve Osmanî akçe olarak belirlenmiş, ayrıca da

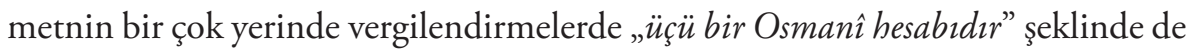
ayrıca ifade edilmiştir. Bu kayıtlarda, kara(ca) akçe ve Osmanî akçe değerlerinin yanısıra Hasanbeyi teriminin de kullanılmış olması dikkat çekmektedir. Dolayısıyla kara akçe ile Hasanbeyi ${ }^{63}$ aynı para birimini ifade etmemektedir. Hasanbeyi resmi Hasan Padişah, ${ }^{64}$ akçesinin değeri olarak kullanılırken aynı dönemde kara(ca) akçe tedavülde olan, daha düşük değerde başka bir gümüş para birimini ifade etmektedir. 1516-1518 tarihli Erzincan Sancağ Kanunnamesi'nde de, bâc-ı büzürg yani gümrük vergisi ve özellikle tamga-i siyâh, yani şehirde satıldıklarında alınan pazar bâcı ve bunlarla bağlantılı olarak alınan, örneğin yazıcılık için ödenen hakk-ul-kalem veya malları teslim alan görevliye ödenen kâbızâne gibi diğer resmlerden, tüccar taifesinden karaca akçe alındığ 1 görülmektedir. ${ }^{65}$ Kanunnamenin köy gelirlerinden alınan şer'î ve örfî rüsumla ilgili birinci kısmı Kânun-ı Osmanı̂ olarak, bâc, tamga ve gümrük vergilerini düzenleyen ikinci kısmı ise Hasan Padişah Kanunu'ndan yararlanılarak oluşturulmuştur. ${ }^{66}$ Buna göre, harir

60 Akgündüz, Yavuz Sultan Selim Devri Kanunnâmeleri, s. 222-224.

61 Akgündüz, Yavuz Sultan Selim Devri Kanunnâmeleri, s. 252-256.

62 Akgündüz, Yavuz Sultan Selim Devri Kanunnâmeleri, s. 266-267, 272-273, 284.

63 Uzun Hasan’a ait küçük gümüşs sikkelerden İstanbul Arkeoloji Müzeleri Teşhirdeki İslami Sikkeler Kataloğu’nda yayınlanmış tek örnek Harput darplı olup 13 mm. çapında, 1,60 gr. ağırlığındadır ve yalnızca gümüş olarak tanımlanmıştır, Artuk ve Artuk, İstanbul Arkeoloji Müzeleri, II, s. 837, nr. 2412.

64 Akgündüz, Kanunî Devri Kanunnâmeleri, s. 441, 475, dipnot 4’de de 932/1526 tarihli Ergani Sancağı Kanunnamesi bahsinde, Hasanbeği için Hasan Padişah adına basılan bir para birimi olduğu açıklaması ve metindeki ifadeye göre dört akçe değerinde olduğu yer almaktadir.

65 Akgündüz, Yavuz Sultan Selim Devri Kanunnâmeleri, s. 296, 297.

66 Akgündüz, Yavuz Sultan Selim Devri Kanunnâmeleri, s. 294. 
yükünden her Hasan Paşa batmanına seksen bir karaca akçe bâc alınmaktadır; bunun on karaca akçesi Kemâh bâcı, yetmiş karaca akçesi ise Erzincan bâcı olarak hesap edilmektedir ve üç karaca akçenin değeri bir Osmanî olarak verilmektedir, ayrıca her batmanda dört karaca akçe tamga-i siyâh, bir akçe hakk'ul'kalem ve bir akçe resm-i kâbızâne tüccarlardan alınmaktadır. ${ }^{67}$

Trabzon'dan gelen keten şehirde satıldığında, her topundan on karaca akçe, keten elbiseden ise yükde yüz elli karaca akçe alınır imiş diye kaydolmuş olup, Osmanlı akçesi değeri yazılmamıştır. ${ }^{68}$ Burada, özellikle kuzey geçede ve güney geçede $e^{69}$ şeklindeki ifadeler dikkat çekicidir ve transit ticaretin coğrafi konumunu vurgulaması açısından önemlidir. Erzincan şehrinin içinden transit geçişlerde alınan verginin mikdarı da verilmektedir; pamuk, bez, ipek için geçip gitse de yük başına otuz altışar karaca akçe ödenmesi gerekmektedir. ${ }^{70}$ İlginç bir ayrıntı da kentteki üretim ile ilgilidir; eğer şehirliler bezi yapsa veya ipeği başka bir yere iletse, yükte altışar karaca akçe ve şehre getirse otuzaltışar karaca akçe vergi alınmakta idi; Urum'dan getirilen kumaşlardan ise batmanda yirmisekiz karaca akçe bâc-ı büzürg (gümrük vergisi) yanısıra dört karaca akçe tamga-i siyâh (pazar vergisi), bir karaca akça hakk’ul kalem ve bir karaca akçe kâbızâne ile vergilendirilmekteydiler. ${ }^{71}$ Rum'dan gelen işlenmiş bakır, kalay, şeker, deri, bıçak vb. bir çok ürün Erzincan şehrinde satıldığında yüzde beş tamga alınmaktaydı ve karaca akçe ile ödeme yapılmaktaydı; örneğin bakır yükünden alınan yüzdoksan sekiz karaca akçenin doksan akçesi bâc-ı büzürg, seksen dört akçesi tamga-i siyâh ve onsekiz karaca akçesi Tercan'da Vartek kalesinin vergisidir. ${ }^{72}$ Kemah sancağındaki 1518 yılındaki tahrirde de, tamga ve bâc kanunnamelerinde Hasan Padişah kanunnamelerinin aynı kaldığı ve nokta başı olduğu için transit geçişlerde, satışlarda ve tabakhane gibi üretim yapan yerlerden tamga-i siyâh gibi pazar vergisi olmak üzere bütün vergilerin karaca akçe üzerinden alındığı görülmektedir. ${ }^{73}$

67 Akgündüz, Yavuz Sultan Selim Devri Kanunnâmeleri, s. 295-296.

68 Akgündüz, Yavuz Sultan Selim Devri Kanunnâmeleri, s. 296, madde 22.

69 "Ve kuzey geçede hâsilindan yetmiş penbe alurlar imiş ve güney geçede mevzi-i Beraslu'dan tâ bunda varunca nekadar mevzi” vâki bir cüllah kuyusından altı̧̧ar karaca akçe alırlar imiş. Ve yiğirmi arşun bezden dört karaca akçe alurlar imiş. Ve yiğirmi arşun alacadan altı karaca akçe alırlar imiş", Akgündüz, Yavuz Sultan Selim Devri Kanunnâmeleri, s. 297, madde 26.

70 Akgündüz, Yavuz Sultan Selim Devri Kanunnâmeleri, s. 297, madde 27.

71 Akgündüz, Yavuz Sultan Selim Devri Kanunnâmeleri, s. 297, madde 28, 29.

72 Akgündüz, Yavuz Sultan Selim Devri Kanunnâmeleri, s. 296, madde 23.

73 Akgündüz, Yavuz Sultan Selim Devri Kanunnâmeleri, s. 300, madde 13-16. 
Bölgede, halkın önceleri Hasan Paşa Kanunnameleri'nin uygulanmasını istemesine karşın sonradan, özellikle para, ölçü, tartı ve örf-adetlerde hukuki işlemlerde yaşanan zorluklar nedeniyle Rum kanunu da denilen Osmanlı Kanunu'na tabi olmak için arzlar gönderdiği bilinmektedir; bunlardan ilki Kemah ve Bayburd bölgesidir ve bu talebler sonucu 1520 yllında değişiklikler gerçekleştirilmiştir. Ardından Erzurum Kanunnamesi ve Diyarbakır kanunları gelmiştir. ${ }^{74}$

Kanunî döneminde de, 932/1526 tarihinde Diyarbakır Eyaleti'nde Hasan Paşa Kanunnameleri tasfiye edilerek Çermik ve Ergani Kanunnameleri hazırlanmıştır. İlk defa 947/1540 tarihinde Diyarbakır Eyaleti'ne ait umumi bir kanunname, Osmanlı Kanunu çerçevesinde yeniden düzenlenmiş ve bu kanun asırlarca Diyarbakır Eyâleti'nin idaresi için esas olmuştur. ${ }^{75}$ Bu kapsamdaki 1540 tarihli Boz Ulus Kanunnamesinde, Mardin ülkesinden uğramayıp Berriyecik ülkesine uğrayan Ulus taifesinden tâ Murad kenarına varıncaya kadar Karacadağ Yaylası diye vergi alındığ belirtilerek, defter-i cedid-i hâkanîde Karacadağ' in kadim sınırının belirlendiği, bunun dışında kalan yerlerden Karadağ Yaylağı adı altında hiçbir vergi alınamayacağı yazılıdır. ${ }^{76}$ Buradaki coğrafi tanımlama, kara(ca) akçenin adı ve tedavül bölgesi için de önemli bir gönderme olarak değerlendirilmelidir.

Kanunî Sultan Süleyman dönemindeki 932/1526 tarihli, Diyarbakır Eyaleti'nin ocaklık ve yurtluk olarak yönetilen ekrâd sancaklarından Çermik Sancağ kanunnameleri arasında Ebu Tahir nahiyesine ait kanunnamede, debbağhane ile ilgili yapılan düzenlemelerde daha önceki uygulamalara atıfta bulunularak, alınan meblağlar karaca akçe üzerinden belirtilerek, ve "yine ol üzere mukarrer kılindiğg" kaydedilmiştir. ${ }^{77}$ Tamga-i ağnam için de uygulama esasları belirlenmiştir. ${ }^{78}$ Aynı

74 Akgündüz, Kanunî Devri Kanunnâmeleri, s. 441, 442.

75 Akgündüz, Kanunî Devri Kanunnâmeleri, s. 441, 442.

76 Akgündüz, Kanunî Devri Kanunnâmeleri, s. 460, madde 3. Beriyyecik bölgesi ile Birecik veya Bira aynı değilse de yakın alakalıdır.

77 "Ve debbâğğhâne hususı dabi her iki koyun ve keçi derisi dibâgate gelür olsa, her iki posta bir karaca akçe alınurmış. Ve sığır gönünden bir buçuk ve camus gönünden ü̧̈er akçe alınurmı̧̧, yine ol üzere mukarrer kılınd»", Akgündüz, Kanunî Devri Kanunnâmeleri, s. 473, madde 5.

78 "Ve tamgâ-i ağnam dabi eğer şehirde kurâlarda satılmak için boğazlanan koyundan her koyun başına altı̧̧ar karaca ve sığırdan on sekiz karaca akça tamga alınırmış ki, üçi bir Osman akçesi olur diye kayd olunmuş. Her koyun başına altı̧̧ar akçe ve sıٌ̆̆r başına altı̧̧ar akçe alına", Akgündüz, Kanunî Devri Kanunnâmeleri, s. 473, madde 6. Burada, eğer yazım hatası yok ise, verilen koyun başına ödenecek miktar muhtemelen altı karaca akçe olmalıdır; sığır için belirtilen altı akçe ise Osmani akçe hesabıyla 18 karaca akçeye denk gelmektedir. 
tarihli Ergani Sancağı Kanunnamesi'nde aynı konu için aynı şekilde kara(ca) akçe kavramı kullanılmıştır; bu metinde her iki para biriminin değeri net olarak ortaya çıkmaktadır. ${ }^{79}$ Mardin Sancağı Kanunnamesi de aynı tarihli olup ipek yükünden ve Haleb tarafından gelen yükden melikü-l ümeralık olarak on karaca akçe alındığı belirtilmektedir; beğlerbeği adına tahsil olunan bu örfi verginin de devam ettirildiği görülmektedir. ${ }^{80}$ Aynı kanunnamede, eskiden olduğu gibi, hârir yükü geçüb giderse, her yükünden iki Osmânî akçe resm-i bevvâbî alınması uygun görülürken, akmişe yükü geçüb giderse her yükünden dört karaca akçe resm-i bevvâki alınması karara bağlanmıştır. ${ }^{81}$ Burada hârir için Osmanlı akçesi üzerinden vergi alınırken diğer kumaşların karaca akçe üzerinden vergilendirilmesi dikkat çekicidir. Der Beyân-ı tamgâ-i siyah ve kayseriyye altında, Mardin şehrinin merkezinde de ipek işlenen tezgahlardan alınan ayda dörder karaca akçe ödenmesi hükmü sürdürülürken, "bez dokuyup bazara getiren cüllablardan bir çift bezden iki karaca akçe" tamga alındığı kayıtlıdır. ${ }^{82}$

Aynı kanunnamenin Resm-i Bevvabi-i Diğer başlı̆̆ı altında ise re’âyanın hâsılından alınacak resm-i bevvabi için "defter-i sâbıkta vere-gelen kurâlardan" alınması, diğer köylerden alınmaması, "kurâ ahalisinin pazara gelenlerinden eskiden de alınmadiğ $\imath$, yine alınmaması” kayd olunmuş, gelen tepkiler üzerine, değişiklikler yapılarak her yükden bir karaca akçe ödenmesi karara bağlanmıştır. ${ }^{83}$ Yapılan bu

79 "Ve tamgâ-i ağnam dahi eğer şehirde kuâlarda satılmak için koyun boğazlansa her koyun başına altışar akçe-i karaca ve sığırdan sekizer karaca akça tamga alınırmış; üçi bir Osmani akçe hesâbı üzere kayd olunmuş. Her koyun başına iki akçe ve sı̆̆ır başına altı̧̧ar akçe alına", Akgündüz, Kanunî Devri Kanunnâmeleri, s. 476, madde 5.

80 "Ve ipek yükünden ve Haleb canibinden gelen yükden on karaca akçe melikü-l ümeralık alınurmıs. Ve on akçe tamgâ alınan (yerden) bir akçe dabi alınurmış. Yine ol üzre mukarrer kılındı", Akgündüz, Kanunî Devri Kanunnâmeleri, s. 479, madde 7.

81 "Ve hârir yükü geçüb gitse, her yükünden resm-i bevvâki iki Osmânî akçe resm-i bevvâbî ve akmişe yükü geçüb gitse her yükünden dört karaca akçe resm-i bevvâki alınurmı̧ yine ol üzre mukarrer kılındi”, Akgündüz, Kanunî Devri Kanunnâmeleri, s. 481, madde 16.

82 "Nefs-i Mardin’in ipek işlenen dezgâhlarından ayda dörder karaca akçe alınurmış. Ve vâlenin topun satsalar, ayruk nesne vermezlermiş. Ve cüllablar ki, bez dokuyup bazara getürse, bir çift bezden iki karaca akçe tamga alınurmış", Akgündüz, Kanunî Devri Kanunnâmeleri, s. 481. madde 19.

83 "Ve sâir kurâlardan her yükden bir karaca akçe alınurmış. Ammâ ol kurâlardan ki, yüz müdd'de nîm müdd-i Mardinî alınurmı̧̧, ol zamanlarda yedide, sekizde bir behre alınurmış. Şimdi, 'hod cem’imiz beşde bir behre verirüz. Sebeb nedir ki, bu bid'at alına? Biz dahi, sâir kurâlar gibi yükde bir karaca akçe veririz’ deyü cevab ettikleri sebebden anlar dabi bu üzere kayd olunup tảyîn olundu”, Akgündüz, Kanunî Devri Kanunnâmeleri, s. 481, madde 18. 
değişiklikte, bu tür uygulamalarda, eski kanunların metinlerinin tamamen aktarılmadığı, dolayısıyla buradaki karaca akçe teriminin de değiştirilmesinin sözkonusu olabilecekken değiştirilmediği bir kez daha görülmektedir.

1541 tarihli Çemişgezek Sancağı Kanunnamesinde, bâc konusunda eski kanununun zikr edildiği, ancak karaca akçe terimine hiç yer verilmediği görülmektedir; bütün rakamların yalnızca akçe olarak yazılması dikkat çekmektedir. Burada harir yükü ile ilgili "ubûr etse, her yükünden yüz elli akçe bâc alınur ve on iki akçe noktabaşı deyü alınur" ${ }^{\prime 4}$ denmektedir ki, bir transit kapısı olarak yorumlanmalıdır.

Bu dönemde, kara(ca)a akçenin sikke olarak tedavülde olup olmadığı konusunda, H. Sahillioğlu doktora tezinde bir dipnotta, bu sikkenin muhtemelen Doğuda kullanılan bir para olduğunu belirtmekte, ancak Kanuni devrinde yeni tahrirler yapılırken kara(ca) akçenin mevcut bulunmasını uzak bir ihtimal olarak görmektedir. Bunların ancak hesap parası olarak istimaline devam edilmiş olmasının kuvvetle muhtemel olduğunu belirtmektedir. ${ }^{85}$ Ancak, karaca akçenin sadece hesaplamalarda kullanılmadığı, Kanuni devrinden sonra da yerel olarak tedavülde olan bir para olduğu aşağıda görüleceği gibi Osmanlıca belgelerdeki kayıtlardan anlaşılmaktadır.

II. Selim dönemine ait 975/1567-1568 tarihinde yazılan ve Tapu Kadastro Kuyûd-1 Kadîme Arşivi TT.d nr. 106 (201) 67-69 sayfalarındaki Harpurd Sancağ1 Kanunnamesinde de kara akçe ile ilgili bilgiler vardır. ${ }^{86}$ Harpud, Kanuni döneminde de Diyarbakır Eyaletine bağlı bir sancaktır. Yavuz Sultan Selim devrinde Diyarbakır Eyâleti kanunnameleri yayınlanırken Harpurd Sancağı Kanunnamesi'nde Hasan Padişah hükümlerinin muhafaza edildiği görülmektedir. ${ }^{87}$

Kara(ca) akçe, II. Selim dönemindeki 975/1567-1568 tarihli tahrirde, yine geçişlerde ödenen bir vergi ve tamga olarak karşımıza çıkmaktadır. Ebu Tâhir Kanunnamesi de Harput Sancağı Kannunnamesi'ne mezcedilmiştir. Kanunnâme-i

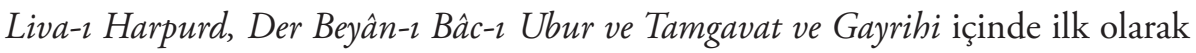
daha önceki uygulamalara atıfta bulunularak harir yükünün vergilendirilmesi konusunda, Amid'e uğramadan Çapakçur ve Ebu Tâhir veya başka bir yoldan

84 Akgündüz, Kanunî Devri Kanunnâmeleri, s. 531, madde 22; diğer bütün sayılarda da yalnızca akçe terimi kullanılmıştır.

85 Sahillioğlu, "Kuruluşundan XVIII. Asrın Sonlarına Kadar Osmanlı Para Tarihi”, s. 60.

86 Ahmed Akgündüz, Osmanlı Kanunnâmeleri ve Hukukî Tablilleri, VII/2: II. Selim Devri

Kanunnâmeleri (İstanbul: Osmanlı Araştırmaları Vakf1, 1994), s. 542 v.d.

87 Akgündüz, II. Selim Devri Kanunnâmeleri, s. 542. 
gelen ipek yükünden, 1800 dirhem olan Harpurd batmanı üzerinden, batman başına doksan karaca akça $b \hat{a} c^{88}$ alındığı, bunun otuz Osmanî akçe olduğu ve her batmandan da dörder karaca akça tamga alındığı yazmaktadır. ${ }^{89}$ Amid'e uğrayanlardan alınacak vergi için ise, oradaki ödemeden sonra elinde bir belgesi var ise, her yükten kırk akçe bâc ve her batmândan dörder karaca akçe tamga alındığı belirtilmiştir. ${ }^{90}$ Sonra mahruse-i Amid'de tartıldı̆̆ı halde, Amid'e uğramadan geçen ipeğe el konacağının emredildiği ve bütün ipek yükünün Amid üzerinden olmasının, rüsumunun verilmesinden sonra geçmesinin sağlandığı ve "her yükden 50 Osmanî bâc ve her batmanda ise 4 karaca akçe tamga alınmak üzere defter-i atikde mukayyed bulunmağın, defter-i cedide dahi olıgeldiği üzere mukarrer kılındı" denmektedir. ${ }^{91}$ Burada, karaca akçe üzerinden verilen tamga değerinin karşısında Osmanlı akçesi verilmeden yeni deftere aktarılması dikkat çekicidir. Kanunnamede yer alan diğer maddelere bakıldığında, genellikle $b \hat{a} c$ için Osmanî akçe üzerinden değerlerin verilmesi, tamga için ise karaca akça kullanılması, tamga ödemelerinde hâlâ karaca akçe kullanıldığını belgelemektedir. Yine dişarıdan gelen mal için tamga "ve Ebû Tâhir'den gelen yaş üzüm yükünden iki karaca akçe tamga alınır; amma şehirlü getürüb satarsa nesne alınmaz" olarak belirlenmiştir. ${ }^{92}$ Muhtemelen yerel üretim olan pamuk ve iplik pazara getirilip satıldığında hem bac hem de pamuklu kumaş için alınacak tamga Osmanlı akçesi üzerinden verilmiştir. ${ }^{93}$ Ancak, Trabzon'dan gelen keten bezi satıldığında, vergi Osmanî akçe üzerinden, şehir merkezinde ise tamga karaca akçe olarak verilmiştir. ${ }^{94}$

88 Osmanlılar'da bâcın genel olarak vergi anlamında kullanıldığı, şehirlerde alınıp satılan her çeşit maldan, dokunan kumaşlardan ve kesilen hayvanlardan alınan damga vergisine bâc-1 tamga denmesi, gümrük resminin adının bâc-1 büzürg (büyük bâc) olduğu bu vergiye tâbi mallar pazarda satılırken ayrıca damga (bâc) vergisine tâbi tutulması konusunda bkz. Celal Yeniçeri, "Bâc", Türkiye Diyanet Vakfi İslâm Ansiklopedisi (DİA), 1991, IV, 411-413.

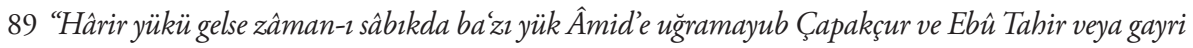
yoldan gelse, gelen hariri yükünü vezn edib Harpurd batmân ki, bin sekiz yüz dirhem olur, her batmânindan doksan karaca akçe bâc alınurmış ki otuz 'Osmanî akçe olur. Ve her batmândan dörder karaca akçe tamga alınurmıs”, Akgündüz, II. Selim Devri Kanunnâmeleri, s. 542, madde 1.

90 "Amma mahrûse-i Âmid'e uğrayub anda olan 'âdeti verüb elinde temessüki olsa, her yükünden kırk akçe bâc ve her batmândan dörder karaca akçe tamga alınurmış", Akgündüz, II. Selim Devri Kanunnâmeleri, s. 542, madde 2.

91 Akgündüz, II. Selim Devri Kanunnâmeleri, s. 542, madde 3.

92 Akgündüz, II. Selim Devri Kanunnâmeleri, s 543, madde 15.

93 Akgündüz, II. Selim Devri Kanunnâmeleri, s. 543, madde 17.

94 "Trabzon ketân bezi satılsa yüzde beş akçe alınmayub hemân her topta iki buçuk 'Osmanî akçe alına ve nefs-i şehirde çehârkezi kuşak tamgalanub rub’ karaca akçe alınur”, Akgündüz, II. Selim Devri Kanunnâmeleri, s. 543. 
Ruha Sancağı'nın II. Selim devrindeki kanunnamesi 976/1568-1569 tarihinde tahrir olunan BOA TT.d No. 965 (802) sh. 8-9' bulunmakta olup Kanuni devri kanunnameleri arasında neşredilen Ruha Kanunnamesi'nin aynısıdır. ${ }^{95}$ Dolayısıyla buradaki karaca akçe ile ilgili hükümler ${ }^{96}$ de devam etmektedir.

III. Murad ve III. Mehmed dönemine bakıldığında, yayınlanan kanunname sayısının çok az olduğu görülmektedir. Osmanlı Devletinin II. Selim devrine kadar devlet nizamı ve hukuk nizamının birlikte yürütülmesi kâidesine genellikle uyulduğu, ancak III. Murad döneminden itibaren bunun sarsılmaya başlandığı tespit edilmiştir. III. Murad'dan itibaren merkezi ve umumi kanunnameler ile her eyâlet ve sancağa ait kanunnameler bulunmamaktadır; ya eskilerin aynen yürürlükte olduğunu belirten tekrarlar vardır, ya da kanunnamelerden hiç bahsedilmemektedir. Kanunnamelerden çok, siyasetnameler ve adaletnamelerle adaletin temin edilmeye çalışıldığı görülmektedir. Bu durum, Osmanlı devletinin duraklama dönemine girişinin bir göstergesi olarak yorumlanmaktadır. ${ }^{97}$ III. Murad ve III. Mehmed dönemine ait yayınlanan çok az sayıdaki kanunnamede karaca akçe tabirine rastlanmaması bununla ilgili olmalıdır. Yeni kanunnamelerin yayınlanmadığı ve karaca akçe ile ilgili bahsedilen bölgelerde III. Murad ve III. Mehmed dönemlerinde karaca akçenin kullanılmasına devam edildiği düşünülmektedir.

Kara(ca) akçenin sikke olarak varlığının kanıtı da bir kayıtta karşımıza çıkmaktadır: Şevval 995/Eylül 1587 tarihli 62 nolu Mühimme Defteri’ndeki bir kayıt ${ }^{98}$ kara akçenin dördü bir Osmanî akçe değerinde sikke olarak kesildiğini

95 Akgündüz, II. Selim Devri Kanunnâmeleri, s. 555.

96 Akgündüz, Kanunî Devri Kanunnâmeleri, s. 492-496.

97 Akgündüz, Osmanlı Kanunnâmeleri ve Hukukî Tablilleri, VIII/1: III. Murad Devri Kanunnâmeleri, (İstanbul: Osmanlı Araştırmaları Vakfı, 1994), s. 8 ve kitaptaki ilgili bölümler.

98 "Han Hazretlerine nâme-i humâyun yazıla ki: Mektub gönderib Jane vilayetinde isyan olmă̆la Çerkesler itaat altına alındĭ̆ı ve dördü bir Osmanî akçe değerinde kara akçe kesilüb bunun hakkında fetva ve kadı bükmü alındı̆̆ı ve Mübarek Giray ve Selamet Giray’n cerime aldı̆̆ı haberi doğru olmadığı bildirilmekle esasen bu gibi sözlere bu tarafta kulak verilmediği fakat olagelmişe muhalif bir vazı ihdas etmeyüb beyhude söz söylenmesine sebeb olmaması hakkında", BOA, Mühimme Defterleri (A.DVNS.MHM.d), nr. 62, s. 297/133. Ayrıca krş. Celil Ender, Başbakanlık Devlet Arşivleri Osmanlı Arşivindeki Nümismatik ile İlgili Belgeler Kataloğu (Darphaneler, İlgili Kuruluşlar, Madenler, Meskûkât, Kaime, Madalya, Nişanlar vb.), (İstanbul: Türk Numismatik Derneği Yayınları, 1996), s. 17; bu makalede verilen, bu yayında da yer alan diğer Mühimme Defterleri kayıtları anlam farklılıkları olmadığı sürece ayrıca verilmeyecektir. 
bildirmektedir. ${ }^{99}$ Çerkeslerin isyanının Kırım Hanları yardımıyla bastırılmasından sonra, Kuzey Kafkasya bölgesinde kesilen bu sikke için fetva ve kadı hükmü de alınması, bu sikkenin devlet kontrolünde basılan resmi bir akçe olduğunun ve Osmanî akçe ile arasındaki kur oranının 4/1 olduğu belgelenmektedir. Bu hüküm, bize aynı zamanda karaca akçenin Kırım Hanlarının parası olan Kefevi akçeden de farklı bir para birimi olduğunu ispatlamaktadır. Kefe limanı ile Trabzon limanı arasında sıkı bir ticari faaliyet olduğ ${ }^{100}$ göz önüne alındığında, karaca akçenin bu amaçla basıldığı varsayımı güçlenmektedir. 1588 yılında olduğu öngörülen büyük devalüasyondan önce III. Murad'ın bazı akçelerinin ağırlıklarının, 0,76 gr. civarında olduğu, 0,80 grama kadar ulaşıı̆ı numizmatik verilerle ortaya konmuştur. ${ }^{101}$ Bunun ağırlığı, 4 karaca akçe 1 Osmanlı akçesi değeri üzerinden hesapladığımızda yaklaşık 0,16 gr. ile 20 gr. kadar olmaktadır. Bu bağlamda, Anadolu Muhasebeciliği gibi önemli görevlerde bulunan Mustâfâ Selânikî tarafından verilen bilgi önem kazanmaktadır; 17 Cemaziyülevvel 997/3 Nisan 1589 tarihinde Beylerbeyi Mehmed Paşa ve Defterdar Mahmud Efendi'nin idamını anlatmakta ve 100 dirhem gümüşten 2000 akçeye kadar hurda/küçük akçe basıldığını yazmaktadır. ${ }^{102}$ Muhtemelen 1588 öncesindeki kara(ca) akçeyi kastetmektedir. Yukarıda da değinildiği üzere aktardığı bu olayın haberi kendisine Doğu seferinde görevli olduğu Erzurum'da iken 4 Cemaziyülahir 997103/20 Nisan 1589 tarihinde ulaşmıştır ki bu tarihte büyük devalüasyon gerçekleşmişti. Selânikî, bu eleştiriler bağlamında 1 dirhem gümüşün 12 akçe değerinde olduğunu bildirmektedir. ${ }^{104} \mathrm{Bu}$ bilgiye göre, 1 akçenin ağırlığı 0,256 gr. yapmaktadır ki, bu vezin kara(ca) akçe vezni ile örtüşmektedir. Selânikî Doğu seferinde iken yazdığı aktarımında muhtemelen Doğu darphanelerinde basılan bu hafif vezinli kara(ca) akçeleri kastetmektedir.

99 BOA, Mühimme Defterleri (A.DVNS.MHM.d), nr. 3, Hüküm no: 527'de “Cane”, 961 ve 1266 numaralı hükümlerde "Jane” şeklinde Kefe civarındaki Çerkezlerden bahsedilmektedir.

100 Yücel Öztürk, Osmanlı Hakimiyetinde Kefe (1475-1600) (Ankara: Kültür Bakanlığı Yayınları, 2000).

101 Pfeiffer-Taş, “New Remarks Regarding Ottoman Monetary History”, s. 489-507.

102 Pfeiffer-Taş, “Zur Geldgeschichte im Osmanischen Reich”, s. 79 ve buradaki tartışma.

103 Bu tarih, Selânikî̀nin Erzurum'da seferde olmasından dolayı İstanbul'da bulunmadığı için, kendisine bilginin ulaştığı tarihtir; krş. Pfeiffer-Taş, "Zur Geldgeschichte im Osmanischen Reich", s. 79; Pfeiffer-Taş, "New Remarks Regarding Ottoman Monetary History”, s. 489-507.

104 Bilginin bütün nüshalarındaki karşılaştırma için bkz. Tarih-i Selânikî, I, s. 210. 
16. yüzyılın sonlarında da, bu para biriminin bir sikke olarak tedavülde olduğu konusunda başka bilgiler de vardır. Ancak, yaklaşık 1588'den sonra Osmanlı akçesinin vezninin 0,38 gram olmasından dolayı kara(ca) akçanın da vezni değişmiş olmalıdır. 4 adetinin bir Osmanlı sikkesi değerinde olabilmesi için kara(ca) akçenin yaklaşık 0,095 gr. ağırlığında basılması gerekirdi ki, teknik olarak bu olası gözükmemektedir. Bundan dolayı vezin, aşağıda verilen belgelerden takip edilebildiği gibi 4/3 oranı esas alınarak değiştirilmiş olmalıdır.

H. 1004-1008/1595-1600 yılları arasında Şeriyye Sicilleri'ndeki bazı kayıtlarda kara(ca) akçe, tedavülde olan diğer para birimleri karşısındaki raiç bedelleri ile birlikte verilmiştir. Bunların içinde, ulufe mevacibleri için akçe olarak belirtilen meblağların yanına kara(ca) akçe cinsinden olduğundan dolayı bunların değeri Osmanî akçe olarak da verildiği yazılı olanlar oldukça dikkat çekmektedir.

28 Zilhicce 1007/22 Temmuz 1599 tarihli bir Şeriyye Sicili kaydında, 17 Zilkade 1007/11 Haziran 1599 tarihinden itibaren 1 yıl süre ile Mardin'deki boyahane, kapan ve bazar-i esb, ağnam, ve boyahane-i Karadere ve ebvab-i selase tevabi ve levahikiyla 340.000 akçeye iltizam edildiği bildirilirken, ilginç bir ayrıntı öne çıkmaktadır; kara(ca) akçenin diğer para birimleri karşısındaki kur değeri de verilmiştir. Yani kur değerinin hesaplanması konusunda bir akid söz konusudur. 340.000 akçeye uhdesine alan kişi, altını 200 kara akçeye, guruşu 143 kara akçeye ve arslanî kuruşu 132 kara akçeye ve şahîyi 11'er kara akçeye vererek eda etmeyi kabul ve iltizam etmiştir. ${ }^{105}$

105 "Şehir kethüdâsı Murâd Ağa bin Kara Velî mahvîl-i kâzada Emîr Mehmed Çelebi ibn-i Emîr Feyyâz Çelebi ve Mehmed bin Şeyh Mûsâ ve Dellâl bin 'Abduldầim mahzarlarinda takrîr-i kelâm kılub Mardin'de vâkî̀ olan boya-hâne ve kapan ve bâzâr-ı esb ve ağnam ve boya-hâne-i Karadere ve ebvâb-ı selâse tevâbi' ve levâhı kıyla iş bu sene seb'a ve elf zîlka'desinin on yedinci gününden bir seneye varnca Mardin voyvodası fahrül-efâhim ve’l-ekârim Cảfer Ağa zâde kadrûhudan üç yüz bin ve kırk bin akçeye uhdeme alub kabûl ve iltizâm itdim ki altunı iki yüz kara akçeye ve guruşu yüz kırk üç kara akçeye ve aslanî guruşu yüz otuz iki kara akçeye ve şâhîyi on birere kara akçeye virüb edâ ideyüm hâlen mezkûrlart târîh-i mezkûrdan bir seneye varınca mukâta'ât-ı mezkûreye galle şerîk itdim ki ne mikdâr asıl ve ziyân olırsa mâbeynimizde 'alâs'seviye ola deyicek mezkûr Emir Mehmed Çelebi ve Mehmed ve Dellâl mukır-ı mezkûrın vech-i meşrûh üzre bi'l muvâcehe ikrârın tasdîk ve şirketi kabûl idüb ma-vaka'a tarafeynin rizâ ve talebleri ile kayd-ı sicill olındr. Fi 28 Zîlhicce sene seb’a ve elf Şuhûdül-hâl Emîr Ahmed Ağa Ağa-i 'Azebân-ı Mardin Üstâd Mahmûd bin Şeyh Pî̀̂ิ Mehmed bin Halîl el Batas? Mahmûd bin el-hâcc Şerefüddîn Hâfız bin Molla Hüseyin bin Kör Cum'a Mehmed bin Bâri ve gayrihîm minel-hâzırûn", Ramazan Günay, "259 Numaralı Hicri 1006-1008 (Miladî 1598-1600) Tarihli Mardin Şer'iyye Sicilinin Transkripsiyon ve Değerlendirmesi” (Yayımlanmamış yüksek lisans tezi), Dicle Üniversitesi Sosyal Bilimler Enstitüsü, 2002, Belge 796. 
Burada şahînin de belirtilmiş olması ilginçtir; çünkü basımı bu tarihten önce bir kaç kez yasaklanmıştır. İran kaynaklı büyük bir gümüş para olan şahî ${ }^{106}$ bölgedeki ticaretteki yaygınlığından dolayı Osmanlının Doğu darphanelerinde de basılmıştır. Osmanlının Güneydoğu toprakları ile başta İran olmak üzere diğer komşularının bir entegre ekonomik alan oluşturmasında etkendir. Osmanlı ekonomisinin kötüleşmesinde önemli bir role sahip olduğu için, 1589'da yapılan tashih-sikke uygulaması sırasında, darp edilmesi yasaklanmıştır. Şahînin her yerde Osmanlı akçesinin yerini aldığı şikayetini dile getiren Sadrazam Koca Mustafa Paşa’nın raporu bu kararda etkili olmuştur. ${ }^{107}$ Ancak bu yasağın uygulanması pek mümkün olmamış, 1592'de tekrar yasaklanmıştır. Şahînin Osmanlı sikkeleri üzerindeki olumsuz etkisini Selânikî de yazmıştır. III. Murad'ın ölümünden sonra, onun hükümdarlık süresini analiz ederken ekonomi politikasını eleştirmektedir. Özellikle, Murad'ın Doğu savaşları sırasında "mă̧̆şuş ve müşevveş kemayâr" olarak adlandırdığı, gümüş oranı düşük, sahte ve düşük ayarlı şahîlerin Rumeli’ye kadar geçtiğini yazmaktadır. Geldikleri yere geri gönderildiklerini ancak, bunun çok büyük fiyat artışlarına neden olduğunu kaydetmiştir. ${ }^{108}$ Bu eleştiri de Doğu sınırında, daha düşük vezne sahip akçelerin darp edilmesinin bir nedeni olarak görünmektedir. Şahi, akçe karşısında aşırı değerlenmişti. Bu da şahi darp ettirmek amacıyla, Anadolu'dan Bağdat ve Halep'e gümüş kaçırılmasının nedeniydi. Bağdat'ın yanı sıra, Amid/Diyarbakır, Halep, Canca, Erzurum, Van, Tebriz ve Nahçivan'da şahi darbediliyordu. Devlet, şahinin kur değerinin aşırı yükselmesine ve gümüş kaçırılmasına karşı bir takım tedbirler almış, ancak bunlar kalıcı olamamıştır. ${ }^{109}$ Anlaşılan bu tedbirler arasında, özellikle transit ticarette kullanmak için düşük vezinli akçe darp etmek de vardı.

Yukarıda bahsedilen 22 Temmuz 1599 tarihli Şeriyye Sicili sırasındaki resmi ve serbest kur değerleri şöyledir: Mardin bölgesi için kesin veriler olmasa da,

106 Şahî hakkında ayrıntılı bilgi için bkz. Şule Pfeiffer-Taş, "The Numismatic, Metrological and Fiscal Assessment of Şahi, an Important Coin of the Reign of Murad III", 13th International Congress of Ottoman Social and Economic History (ICOSEH) 1-5 October 2013 Universidad de Alcalá, Spain, (Alcalá 2013), Abstracts, s. 89-90, kongrenin tam metinleri yayınlanmadığı için başka bir dergide yayınlanmak üzere hazırlanmaktadır. Şahi konusunda ayrıca bkz. Pfeiffer-Taş, "Zur Geldgeschichte im Osmanischen Reich” ve PfeifferTaş, “Osmanlı Para Tarihi”.

107 Sahillioğlu, "Kuruluşundan XVIII. Assın Sonlarına Kadar Osmanlı Para Tarihi”, s. 91.

108 Selânikî Mustafa Efendi, Tarih-i Selânikî, Viyana Nüshası, Wien, Österreichische Nationalbibliothek A.F.: Nr. 57, vr. 211a vd. [Bundan sonra Tarih-i Selânikî, VN, olarak kısaltılacak]; Pfeiffer-Taş, "Zur Geldgeschichte im Osmanischen Reich”, s. 80.

109 Pfeiffer-Taş, "Zur Geldgeschichte im Osmanischen Reich” ve burada verilen kaynakça. 
diğer bölgelerde bir altının resmi kur karşılığı 118 akçe, serbest piyasada 200 akçe olarak değişkenlik göstermektedir. Recep 1007/Ocak - Şubat 1599'da resmi kur, ham ipeğe de uygulandığı gibi, bir altın için 118 ve bir kuruş için 68 akçe olarak belirlenmiştir. ${ }^{10}$ Ankara'da altının kuru 22 Zilkade 1007/18 Haziran 1599'da 158 akçe olarak hesaplanıyordu. Birkaç gün sonra, 22 Haziran 1599'da bu değer 200 akçeye çıkmış ve 10 Ocak 1600'e kadar da bu değerde kalmıştır. ${ }^{111}$ Ramazan 1008/Mart-Nisan 1600'de hazinenin resmi alım kuru bir altın için 118 akçe iken, serbest piyasadan mal alımında 160 akçeydi. Halk arasında ise bir altın 190 akçeye el değiştiriyordu. Kuruşun resmi alım kuru ise aynı süre içinde 68 akçe idi. Ücret ödemeleri, altın başına 120 akçe olarak hesaplanıyordu. Taahhüt edilen bir altın karşılığı 200 kara(ca) akçenin 4/3’ü 150 yapmaktadır ki, bir Osmanî akçenin resmî ve serbest piyasa değerinin bu aralıkta olduğu görülmektedir. Resmî kur bir kuruş için, 68 akçe, serbest piyasada 110 akçedir. ${ }^{112}$ Taahhüt edilen bir kuruş karşılığı 143 kara akçe, 4/3 oranı üzerinden hesap edildiğinde Osmanî akçe değeri 107,25 yapmaktadır ki bu serbest piyasa değerine çok yakındır.

Bir aslanî kuruş için ise resmi kur 68-70 akçedir; serbest piyasa 100 ile 120 akçe arasında değişiklik göstermektedir. ${ }^{113}$ Taahhüt edilen 132 kara akçanın 4/3 oranındaki Osmanî akçe değeri 99 akçe etmektedir ki, bu serbest piyasa değerine yakın gözükmektedir.

1 şahî 1590’larda 3,10 gr. ağırlığındadır; 1 şahînin kur değeri 11 karaca akçe olduğuna göre 1 karaca akçenin ağırlığ 1 yaklaşık 0,28 gr. olmalıdır. Bu da bu tarihlerde 0, 38 gr. olan bir akçenin yine 4/3'üne denk gelmektedir. Burada ilginç bir ayrıntı, şahitlerden Emîr Ahmed Ağa’nın, Mardin azabları ağası olmasıdır.

Başka bir kayıtta, Mardin kazasında kale azablarının ulufelerinin ödemesindeki hesaplamalarda iki farklı rakam verilmesi ve daha küçük rakamın karşısında bunun Osmanî akçe olarak diğer rakkamın karşılığı olduğunun yer alması dikkat çekicidir. 17 Receb 1007/13 Şubat 1599 tarihinde Mardin kadısına gönderilen bir tezkirede, ${ }^{114}$ eski defterdar Mehmed Efendi zimmetinde bulunan Erciş kalesi azab-

110 Tarih-i Selânikî, VN, vr. 382a, satır 20-22.

111 Ergenç, "XVI. Yüzyılın Sonlarında”, s. 93; Pfeiffer-Taş, "Zur Geldgeschichte im Osmanischen Reich”, s. 81-87.

112 Pfeiffer-Taş, "Zur Geldgeschichte im Osmanischen Reich”, s. 83-87.

113 Pfeiffer-Taş, "Zur Geldgeschichte im Osmanischen Reich”, s. 82-87.

114 "Mevlânâ Mardin kadısı zîde fezẩilub̂̀ tezkire varıcak Ma'lûm ola ki bundan akdem Mardin kazâsında hâss-ı cedîde tâbi' 'Arbân nam karye kıstından sene dokuz yüz doksan 
larının 1004 senesinde hakettikleri mevacibler için iki farklı meblağ bildirilmiştir: 28.093 akçenin karşılığı olarak 21.069 Osmanî rakamı verilmiştir. Buradaki rakamların son derece kesin olması dikkat çekidir. Bu hesaba göre aradaki oran tam tamına 4/3'dür. Burada kara akçe terimi kullanılmamıştır, ancak yerel bir akçeden bahsedildiği görülmektedir. Azabların kalelerde görev yapmaları nedeniyle yerel para birimiyle ulufelerinin ödendiği anlaşılmaktadır. Bundan önceki kayıtta yer alan diğer resmi para birimlerinin karşılığında ödenecek kara akçe mikdarının teyidine Mardin azablarının ağasının şahid olarak bulunması da azab ödemelerinde kara akçe kullanıldığı görüşünü kuvvetlendirmektedir.

28 Cemaziyülahir 1007/26 Ocak 1599 tarihli bir kayıtta halen Mardin'deki bac-1 ubur kıstından 1 Muharrem 1003/16 Eylül 1594'de Köse Mehmed oğlu Yusuf adlı bir kişinin zimmetine gerekli mal-1 miriden önceden Tebriz'e ihrac olunan Van müteferrikalarının 1002/1593 masar (Muharrem-Safer-Rebiyülevvel) mevacibleri için ulufeyi Satılmış marifetiyle 30.000 akçe ki 27.500 Osmanî karşılığında, eski Defterdar Mehmed Efendi zamanında tahvil ve salyane olunduğu halde, 14 Şevval 1006/20 Mayıs 1598 tarihinde mühürlü bir kı’a hazine tezkiresi verildiği, meblağın henüz tahsil olunamadığı yazmaktadır. Meblağın tahsil edilmesi için dergâh-1 âli kullarından Ali Bey’in gönderildiği belirtilerek, emin-i mezkûrdan eksiksiz olarak tahsil olunması konusunda talimat verilmektedir. Tahsil olunduktan sonra, mühürlü mezbûr havaleye teslim ettirilerek mühürlü hazine tezkiresinin adı geçen mültezime hıfz ettirilmesi istenmektedir; muhasebede borcundan mahsub olunması mümkün olabilmesi için bu gereklidir. Belgenin altındaki imza

dokuz vâcibinde erbâb-ı tımârdan 'İsa nâm kimesne zimmetinden defterdâr-ı sâbık Mehmed Efendi zimmetinde kal'a-i Erciş 'azablarının sene erba'a ve elfde müstehak oldıkları mevâcibler içün 'ulûfeyi kılıç màrifetiyle yigirmi sekiz bin doksan ü̧̧ akçe ki yigirmi bir bin altmış dokuz 'Osmânî ider tahvîl ve sâlyâne olınub müşârun-ileyhin mührüyle sene hamse ve elf ramazânının on dördünci günü târîhiyle müverrah mübürli hazîne tezkiresi virilüb mukâta'a-i mezbûre dahî mukaddemen ibtidâ-i târîhden Mehmed nâm kimesneye virilmekle mezkûr 'ulûfeci varub taleb itdikde mücerred virmemek içün ben taksîd itdirmişim deyu edâsında muhâlefet idüb virmedügini mezbûr 'ulûfeci bu cânibe gelüb i'lâm iyledi imdi meblâğ-ı merkûm taksîtden mukaddem tahvîl olınub ve taksît sonra olmagla meblâğ-ı mezkûrun her vech ile edâsı lâzım gelmegin tezkire virildi vardıkda gerekdir ki bu hususa mukayyed olub göresin fìl vâki' mezkûr Mehmed meblâğ-ı mezbûrı virmeyüb 'inâd itdügi sâhih ise bu def'a bî-kusîr velâ-kusûr tahsîl itdürüb mezbûr ulîfeciye teslim itdiresüz ve mühürlü hazîne tezkiresini akçeyi edâ idenlere hifz itdiresiz ki hîn-i muhâsebede deyninden mahsûb olına şöyle bilesüz tahrîren fi'il yevm ül sâbi'-i 'aşere şehr-i receb ül mürecceb min şuhûr sene seb'a ve elf be Medîne-i Amid el fakîr", Günay, "259 Numaralı", Belge 1391. 
Kaymakam-i defterdar muhibbül-fâkir Ahmed Çavuş'a aittir. ${ }^{115}$ Buradaki bilgilerden de anlaşıldığına göre Van müteferrikalarının ulufelerinin karşılığı olarak verilen ve akçe olarak adlandırılan para birimi büyük bir olasılıkla kara akçe olmalıdır; bu meblağın karşılığı yine Osmanî akçe olarak verilmiştir. Buradaki fark da 4/3 oranındadır. Kayıtta yer alan bilgiler, bu para biriminin Osmanlı devleti tarafından resmi işlemlerde kullanılan ve hazinenin kabul ettiği bir para birimi olduğunu belgelemektedir. Söz konusu ödeme, yine ulufe mevacibleri için tahvil edildiğini göstermektedir; ki söz konusu kale Van'dır.

9 Rebilülahir 1008/29 Ekim 1599 tarihli bir kayıtta, Erciş azablarının 1007/1598-1599 senesi beş mevacibi için 28.000 akçe karşılı̆̆ olarak 21.000 Osmanî yazılıdır. ${ }^{16} \mathrm{Bu}$ kayıtta da kara akçe terimi belirtilmiş olmamakla birlikte farklı bir akçeden bahsedildiği ve bunun karşılığı olarak Osmanî akçe teriminin kullanıldığı görülmektedir. Azabların yerli halk içinden seçilen bir birim olduğu düşünüldüğünde mevacib ödemelerinin de yerel para birimi ile yapıldığı varsayılabilir; bu para birimi de olasılıkla kara akçe olmalıdır. 28.000 akçenin karşılığı olarak verilen 21.000 Osmanî akçe arasındaki kur farkı 4/3 oranındadır. Bu tarihteki akçelerin ağırlığı 0,38 gr. olduğuna göre bunun 4/3 ü yak. 0,28 grama karşılık gelmektedir. Bu oran akçeler üzerindeki numizmatik incelemenin sonuçlarıyla tam olarak örtüşmektedir.

Bu durumda, Osmanlı akçelerinin içerisinde, doğudaki bazı darphanelerin kullandığı farklı bir akçe vezni olduğu görülmektedir. Bu görüş belgelerdeki "sağ akçe”" vurgulaması ile de destek bulmaktadır. Mardin Şeriyye Sicili'ndeki bir kayıtta Mevlana Hasan Efendi'nin 13 Cemaziülevvel 1007/12 Aralık 1598 tarihinde günlük 60 sağ akçe ve vech-i tebid ve tekaüd üzere Mardin dışındaki Kasimiyye Medresesi'nde görevlendirildiği bildirilmektedir. ${ }^{117}$ Burada sağ akçe ifadesi Osmanî akçeyi ifade etse gerektir. Çünkü kadı tarafından yapılan böyle bir görevlendirmede, kalb akçe ile ödeme yapılması zaten sözkonusu olamaz. Bu durumda, çürük akçe veya hurda akçe kavramlarının da daha düşük değerde, yani daha düşük ağırlıktaki kara akçe yerine kullanıldığı düşünülmektedir. ${ }^{118}$

$\mathrm{Bu}$ kayıtlar, bölgenin Osmanlılar tarafından feth edilmesinden sonra bir Osmanî akçenin üç karaca akçeye eşit olduğunu göstermektedir. Şevval 995/Eylül

115 Günay, “259 Numaralı”, Belge 1279.

116 Günay, "259 Numaralı”, Belge 978.

117 Günay, “259 Numaralı”, Belge 1404-1405.

118 Günay, “259 Numaralı”, Belge 1218, 1007 Cemaziyül evvel tarihli Mardin Şer’iyye Sicili kayıtında, "nefs-i şehirde cârî olan hurda akçe hesabı üzere" kaydı geçmektedir. 
1587 tarihli 62 nolu Mühimme Defteri'ndeki bir kayıt Kuzey Kafkasya bölgesinde kara akçenin dördü bir Osmanî akçe olarak darpedildiğini belgelemektedir ki 0,16-0,20 gr. ağırlığında olduğu anlaşılmaktadır. Yaklaşık 1590ların başından itibaren izleyebildiğimiz dönemde ise bu oranın $4 / 3$ şeklinde değiştiğini görüyoruz, yani bu dönemde 0,38 gr. olan Osmanî akçenin 4/3’i 0, 28,5 gr. yapmaktadır. III. Murad'ın geç dönem akçeleri ile III. Mehmed'in erken dönem akçelerinden doğu grubuna giren akçelerinin ağırlıkları yaklaşık 0,28-0,29 gramdır. 1600 tarihindeki vezin değişikliğinden sonra ise bir Osmanî akçenin ağırlığı 0,32 gr. olmuştur; bunun 4/3'ü 0,24 gr. yapmaktadır ki III. Mehmed'in son dönemi ve I. Ahmed'in doğu akçe standardına giren darphanelerdeki ağırlıkları 0,24-0,25 gramdır. Bu vezin, Mustafa Selaniki'nin Rebiülahir 1006/11.11.-20.11.1597 tarihinde aktardığı, 1 dirhem gümüşten 8 akçe kesilemediği, yerine düşük vezinli 12 akçe kesildiği bilgisiyle de örtüşmektedir. ${ }^{119}$ Şevval 1006 ayının ilk 10 gününde yani 9.3.-18.3.1598'de eski Defterdar Âli Efendi, tashih-i sikke uygulamalarına nezaret etmesi amacıyla Sırça Saray Darphanesi nezareti ile görevlendirilmiştir. Saraydaki hazine-i amire-i enderundan 300 yük akçe üzerinde gümüş alınmıştır. ${ }^{120}$ Bunlar eritilmiş ve bir dirhem gümüşten 8 akçe vezni ile darp edilmiştir. ${ }^{121}$ Muhtemelen bu sikkeler, doğu darphanelerinden gelen düşük vezinli akçelerdi ve İstanbul'da Kostantiniye darphanesi için eritilip yeniden basıldılar. 17 Ramazan 1006/23 Nisan 1598'de de yeniçeriler akçenin bozuk olduğunu ve bunlarla ödeme yapamayacaklarını bildirerek ulufelerini almak istememişler, sadrazama giderek bir ayaklanma başlatmışlardır. Bu durum karşısında, üst makamlardaki pek çok memurun işine son verilmiş ve akçeler sağlam olanlarla değiştirilmişlerdir. ${ }^{122} \mathrm{Bu}$ bilgiler, Doğu vezni ile basılan akçelerin İstanbul'a kadar ulaştı̆̆ını ancak, burada kabul görmediği için ayaklanmalara yol açtı̆̆ını ve eritilerek İstanbul'da Osmanî akçe vezni üzerinden tekrar basıldığını düşündürmektedir.

Doğu ile yapılan ticaret için düşük vezne sahip sikke bastırmak bu dönemde yalnızca Osmanlılara mahsus değildi. Habsburg İmparatorluğu da Doğu ile yapılan ticaret için tedavüldeki sikkelerin aynısını, ancak düşük ayarda basarak Doğuya göndermiştir. Osmanlı devleti de anlaşılan benzer bir politikayı uygulayarak daha

119 Tarih-i Selânikî, VN, vr. 348a, satır 13-14; Pfeiffer-Taş, "Zur Geldgeschichte im Osmanischen Reich", s. 82.

120 Tarih-i Selânikî, VN, vr. 359b, satır 13 vd.; Pfeiffer-Taş, "Zur Geldgeschichte im Osmanischen Reich", s. 82-84.

121 M. Tayyib Gökbilgin, “Mehmed III.”, İslam Ansiklopedisi (İA), 1997, VII, 535-547, 546.

122 Tarih-i Selânikî, VN, vr. 357b, satır 16 vd. 
düşük ağırlıkta ancak gümüş oranı yüksek olarak kestirdiği bu akçeleri „kara(ca) akçe” olarak adlandırmıştır. Bu politikanın uygulanması, Doğu’da düşük ayarlı şahi darp etmek amacıyla yüksek gümüş oranına sahip Osmanlı akçesinin ticaret yoluyla dışarı çıkarılmasını önlemek olmalıdır. Muhtemelen bu düşük vezinli akçeler piyasada darp yerlerinden ve bu darphanelere özgü lejandlarından tanınıyordu, yoksa 0,08 gr. gibi bir ağırlık farkının elle tespit edilmesi mümkün olmadığı gibi her harcamada tartılması da olası gözükmemektedir. İstanbul'daki ödemelerde kabul görmemesi de bu ayrımın rahatça yapılabildiğini göstermektedir.

\section{Değerlendirme}

$\mathrm{Bu}$ araştırmanın sorunsalı, 16.yy. boyunca Osmanlı arşiv kaynaklarında yer alan kara(ca) akçe teriminin tedavülde olan bir para birimi olup olmadığının ortaya konmasıdır. Bunun için Beçin Definesi’ndeki Osmanlı akçelerinin üzerinde yapılan numizmatik ve arkeometri araştırmaları eşsiz bir olanak sunmuştur. Numizmatik biliminin Viyana okulu yöntemleri kullanılarak yapılan ayrıntılı araştırmalar, III. Murad, III. Mehmed ve I. Ahmed dönemine ait, bütün ve uzun hükümdarlık dönemlerini kapsayan çok sayıda akçenin, genelde üzerlerinde yalnızca tahta çıkış yılını gösteren darp yılı olmasına rağmen kendi içinde kronolojik olarak sıralamak mümkün olmuştur. Osmanlı numizmatik araştırmaları açısından bu çok değerli veriler para tarihi hakkında yeni bilgilere ulaşılmasını sağlamıştır. Numizmatik araştırmaların sonuçlarının Osmanlı arşiv kayıtlarından derlenen bilgilerle örtüştüğü tespit edilmiştir.

Araştırmanın en ilginç sonuçlarından birisi, definede Doğu grubu olarak belirlenen bazı darphanelerde resmi olarak basılan akçelerin ağırlıklarının diğerlerinden belli bir oranda daha düşük olmasıdır. Bu fark, Osmanlı akçesi olarak adlandırılan akçelerdeki resmi vezne bağlı olarak oransal değişiklik göstermektedir.

Yazılı kaynaklardaki bilgiler de, 16.yy.ın başlarında Doğu bölgesinin Osmanlilar tarafından fethedilmesinden sonra, burada daha önce kullanılan ve Hasan Paşa Kanunlarında yer alan kara(ca) akçenin tedavülde ve üç kara(ca) akçenin bir Osmanî akçeye eşit olduğunu belgelemektedir.

16. yy. sonlarına gelindiğinde de kara(ca) akçenin yalnızca hesaplamalarda kullanılmadığı ve hâlâ tedavülde olduğu anlaşılmaktadır. Şevval 995/Eylül 1587 tarihli 62 nolu Mühimme Defteri’ndeki bir kayıt, Kuzey Kafkasya bölgesinde kara(ca) akçenin dördü bir Osmanî akçe değerinde sikke olarak kesildiğini kanıtlamaktadır. 
1590 yılından itibaren takip edebildiğimiz yazılı kaynaklardaki raic bedeli, kur değerleri vb. veriler kara(ca) akçenin kullanılmaya devam ettiğini göstermektedir. Bu veriler, numizmatik araşıırmaların sonuçları ile de uyuşmaktadır. Devlet kontrolünde basılan akçelerde iki farklı vezin kullanıldığı tesbit edilmiş ve bunlar Stil B ve Stil A olarak adlandırılmışlardır. III. Murad döneminde 1588 civarında yapılan büyük değişiklikten sonra 0,38 gr. Stil $\mathrm{B}$ olarak gruplandırdığımız akçelerin resmi veznini yansitmaktadır.

Stil A olarak adlandırdığımız gruptaki akçeler ise hem tipolojik özellikleri, hem de üzerlerindeki işaretler ve ağırlıkları açısından Stil B'den tamamen farklıdır. III. Murad'ın son dönem ve III. Mehmed'in erken dönem akçelerinin istatiksel verileri, sözkonusu Doğu darphanelerindeki akçelerin ağıllıklarının açık bir şekilde 0,28-0,30 gr. civarında olduğunu göstermiştir. Bu durum, özellikle 1582-1586 yılları arasında gerçekleştirildiği öne sürülen, bizim 1588 civarı olarak kabul ettiğimiz büyük devalüasyondan sonra ve 1600 'deki yeni akçe vezninin uygulamaya konulmasına kadar olan dönemde belirgin olarak ortaya çıkmışıır. 1600 tarihinden itibaren uygulamaya konan 100 dirhem gümüşten 950 akçe darbedilmesinden sonra Osmanî akçe olarak belirtilen akçenin ağırlığı 0,32 gr. olmuştur ki bu vezin III. Mehmed'in B grubundaki akçelerinde doğrulanmaktadır. Aynı dönemi içeren A grubunda ise sikkelerin ağırlıkları 0,24-0,25 gr. civarındadır ki, bu ağırlık yine yazılı belgelerde verilen bilgilerle uyuşmaktadır. Kara(ca) akçe için Osmanî akçe ve diğer para birimleri karşısındaki verilen raiç bedelleri de bu bilgileri doğrulamaktadır.

Sunulan veriler, Osmanlıca yazılı kaynaklarda kara(ca) akçe olarak adlandırılan bu para biriminin, Osmanî akçeden farklı, resmi olarak darpedilen, özellikle Güney Doğu - Doğu Anadolu ile Kafkasya bölgesindeki ticarette, bazı ürünlerin vergilendirilmesinde, kale azablarının ve müteferrikaların ulufelerinin ödenmesinde yerel kullanılan bir sikke olduğunu ortaya koymaktadır. Kanunnamelerde belirtilen malların cinsi, üretim yeri, şehirlere giriş kapısı, satış yeri ve alınacak para biriminin cinsi gibi ayrıntılar incelendiğinde kara(ca) akçenin özellikle transit ticarette kullanıldığı ortaya çıkmaktadır. Bu ticaret bölgesinin dağlarla sınırlı coğrafî konumu ve Karadeniz üzerinden ticaret yoğunluğu da göz önüne alındığında, dolaşım alanı da belirlenmektedir. İran asıllı olan büyük gümüş para şahinin bölgenin sını ötesi ticaretinde ortak para olarak kullanımı nedeniyle Osmanlı darphanelerinde de basıldığı bilinmektedir. Osmanlı akçesi karşısında aşııı değer kazanması bu dönemdeki fiyat artışlarının da nedeni olarak görülmektedir. III. Murad döneminde 1578-1590 yıllarında İran’a karşı sürdürülen savaş da bunda 
etken olmuştur. Şahinin măğş̧̧̧, yani kemayâr darpedilmesi nedeniyle 16.yy. sonlarında darp edilmesi yasaklanmış, ancak kontrolü sağlanamamıştır.

III. Murad, III. Mehmed ve I. Ahmed'in akçeleri üzerinde yapılan arkeometrik analizler, bu dönemde Osmanlı akçelerinin gümüş oranlarının \%95-\%99 lara kadar ulaştığını ve akçelerin gümüş oranlarında tağşiş olmadığını ortaya koymuştur. Ekonomik sıkıntılardan kaynaklanan fiyat artışları nedeniyle 1588'de büyük bir devalüasyon yapılmış, akçelerin ağırlıkları düşürülmüş ancak içindeki gümüş oranı kanunlarda belirlendiği şekilde yüksek kalmıştır. Devlet, tashih-i sikke uygulamalarına giderek akçenin değerini sürekli korumaya çalışmıştır. Kara(ca) akçenin vezninin düşük belirlenmesindeki amaç da, hem Doğudaki sınır bölgesinde değerli Osmanlı akçesini şahiye karşı korumak, hem de ticaret nedeniyle sınır ötesine çıkarılmasını önlemek için olmalıdır. Kara(ca) akçenin hazineye yapılan ödemelerde kullanılmadığı, altın ve kuruşa çevrilerek gönderildiği bu konudaki çok sayıdaki hükümden de anlaşılmaktadır. Ayrıca, yine hesaplarda yer alan "nefs-i Amid'de raic olan akçe hesabı üzre" "Diyarbakır hesabı üzre" "nefs-i şehirde cârî olan hurda akçe hesabı üzere” gibi kayıtlar bu verileri doğrulamaktadır. Hurda akçe/küçük akçe ile düşük ağırlıktaki kara(ca) akçe kastediliyor olmalıdır.

Ancak, ekonomik sıkıntılar nedeniyle devletin Osmanî akçe darpetmek için gümüş bulmakta zorlandığı dönemlerde, Doğu darphanelerinde darp edilen düşük vezinli bu küçük akçelerin İstanbul'a ulaştığı, fakat piyasada kabul görmediği metinlerden anlaşılmaktadır. Aradaki ağırlık farkının elle ve gözle farkedilemeyecek kadar az, yalnızca 0,08 gr. kadar olması, piyasada bu sikkelerin darp yerinden ve sikke lejandından ayırt edilebildiğini düşündürmektedir. Bu nedenle de, yalnızca Doğu darphanelerinde, kendilerine ait stil özelliklerinde basıldıkları öngörülmektedir.

Beçin Definesi araştırmalarında tespit edilen Stil A grubundaki sikkeler, 16.yy. sonlarında Osmanî akçenin 4/1 oranında daha düşük bir vezne sahip, ancak gümüş oranı yüksek, devlet kontrolünde basılmış akçelerdir. Sözkonusu akçeler, Osmanlıca kaynaklarda kara(ca) akçe olarak adlandırılan sikkeler olmalıdır. Osmanlıların fethettikleri bölgelerde, mevcut para birimlerini kullanmayı sürdürdükleri bilinmektedir; bu bölgede de aynı uygulamayı yaparak Hasan Padişah kanunlarında da yer alan kara(ca) akçeyi kullanmaya devam ettikleri görülmektedir. Kara(ca) akçe adını Diyarbakır, Urfa ve Mardin arasında yer alan Karacadağ'dan almış olmalıdır. 1540 tarihli Boz Ulus Kanunnamesinde, Murad kenarına varıncaya kadar Karacadağ Yaylası diye vergi alındığı belirtilerek, defter-i cedid-i hâkanîde Karacadağ’’n 
kadim sınırının belirlendiği, bunun dışında kalan yerlerden Karadağ Yaylağı adı altında hiçbir vergi alınamayacağı yazılıdır. Bu tanımlama da kara(ca) akçenin bu bölgedeki ticaret, bac ve tamga gibi çeşitli vergiler için ve sınır kalelerinde görevli azabların ödemeleri için kullanıldığını düşündürmektedir. Görüldüğü gibi Karacadağ ticaret yolları için doğal bir sınır oluşturmaktadır. Volkanik bir dağ olduğu için buradan çıkartılan siyah bazalt taş bölgenin mimarisine de damga vurmuştur. Siyah bazalt taşın mimarideki hâkimiyeti, kentin adının Roma döneminden beri siyah renk ile birlikte adlandırılmasına da neden olmuştur. Evliya Çelebi de kentin siyah taşla yapıldığı için Kara Amid olarak adlandırıldığını bildirmektedir. ${ }^{123}$ I. Ahmed'in sikkelerinde, Amid'in yanısıra Kara Amid adının da darp yeri olarak görülmesi ${ }^{124}$ dikkat çekicidir. Ancak bu ayrı bir araştırma konusudur.

\section{Yüzyllda Bir Osmanlı Para Birimi: Kara(ca) Akçe}

Öz-Bu araştırmanın sorunsalı, Osmanlı devletinde 16. yüzyıl boyunca Anadolu’nun doğusunda kullanılan, belgelerde kara(ca) akçe olarak adlandırılan para biriminin niteliğini belirlemektedir. Sahillioğlu'nun kısa bir değinmesinin dışında bu akçe hakkında pek fazla bilgi verilmemiştir. Bu nedenle kara(ca) akçenin Osmanî akçe yanında, ayrıca bir muhasebe sikkesi ve tedavülde olan bir para birimi olup olmadığı tartışılacaktır. Osmanlı Kanunnameleri, Şeriyye Sicilleri, Mühimme Defterleri gibi çeşitli belgelerde kara(ca) akçenin, Osmanî akçe karşısındaki değeri, altın, kuruş vb. gibi diğer para birimleri karşısındaki rayiç bedelleri ile birlikte bulunmaktadır. $\mathrm{Bu}$ bilgiler, Osmanlı para tarihindeki gelişmeler kapsamında kronolojik olarak değerlendirildiğinde, Osmanî akçe vezni ile oransal bir ilişki içinde olduğu görülmektedir. Osmanlı numizmatiği konusunda 16. yy. sonunda darbedilen akçeler üzerinde yapılan son araştırmalarda, bazı Doğu darphanelerindeki resmî veznin Osmanî akçeden 4/1 oranında daha düşük olduğu tespit edilmiştir. Bu akçeler, Anadolu ve Rumeli grubu olarak tanımlanan diğer darphanelerde basılan akçelerden stilistik açıdan da farklılıklar göstermektedir ve Doğu grubu olarak adlandırılmıştır. Özellikle, vergi ve ticaret ile bağlantılı olarak Osmanlıca belgelerde de Osmanî akçe karşısındaki kur değeri 4/1 oranında daha düşük olan bir para biriminin varolması dikkat çekmektedir. Bu çalışmada, bu sikkenin yalnızca kur belirleyen bir para birimi olmadığı, tedavülde bulunduğu ortaya konmaya çalışılacaktır.

Anahtar kelimeler: Osmanlı para tarihi, ekonomi tarihi, 16. yüzyıl, ticaret, numizmatik.

123 Emine Ekinci Dağtekin, “Coğrafi İşaret Olarak Diyarbakır Bazalt Taşı ve Tescili”, Elektronik Sosyal Bilimler Dergisi, 17, 66 (2018), s. 855-856 ve bkz. burada verilen kaynakça.

124 Vezinle ilgili tartışma için bkz. Şule Pfeiffer-Taş ve Nikolaus Schindel, "Ein Münzkonvolut aus der Regierung des osmanischen Sultans Ahmed I. (1603-1617) im Museum von Tire”, Wiener Zeitschrift für die Kunde des Morgenlandes, 99 (2009), s. 249-280. 


\section{Kaynaklar}

\section{Arşiv Kaynakları}

Başbakanlık Osmanlı Arşivi (BOA), Mühimme Defterleri (A.DVNS.MHM.d), nr. 3, 26, 62,64 .

Selânikî Mustafa Efendi, Tarih-i Selânikî, Viyana Nüshas1, Wien, Österreichische Nationalbibliothek A.F.: Nr. 57.

\section{İkincil Kaynaklar}

Akdağ, Mustafa: “Osmanlı İmparatorluğu'nun Kuruluş ve İnkişafı Devrinde Türkiye’nin İktisadi Vaziyeti”, Belleten, 13 (1949), s. 497-571.

Akgündüz, Ahmed: Osmanlı Kanunnâmeleri ve Hukukî Tablilleri, III: Yavuz Sultan Selim Devri Kanunnâmeleri, İstanbul: Fey Vakfi Yayınları 1991.

Akgündüz, Ahmed: Osmanlı Kanunnâmeleri ve Hukukî Tahlilleri, V/2: Kanunî Devri Kanunnâmeleri, İstanbul: Fey Vakfi Yayınları 1992.

Akgündüz, Ahmed: Osmanl Kanunnâmeleri ve Hukukî Tahlilleri, VII/2: II. Selim Devri Kanunnâmeleri, İstanbul: Osmanlı Araştırmaları Vakfı Yayınları 1994.

Akgündüz, Ahmed: Osmanlı Kanunnâmeleri ve Hukukî Tablilleri, VIII/1: III. Murad Devri Kanunnâmeleri, İstanbul: Osmanlı Araştırmaları Vakfı Yayınları 1994.

Artuk, İbrahim ve Cevriye Artuk: İstanbul Arkeoloji Müzeleri Teşhirdeki İslâmi Sikkeler Kataloğu II, İstanbul: T.C. Başbakanlık Kültür Müsteşarlığı Yayınları 1974.

Aykut, Nezihi: “Osmanlı İmparatorluğu’nda XVII. Asır Ortalarına Kadar Yapılan Sikke Tashihleri”, Prof. Dr. Bekir Kütükoğlu’na Armağan, İstanbul: İstanbul Üniversitesi Edebiyat Fakültesi Basımevi 1991, s. 343-360.

Barkan, Ömer Lütfi: “Onaltıncı Asrın İkinci Yarısında Türkiye'de Fiyat Hareketleri”, Belleten, XXXIV/136 (1970), s. 557-607.

Barkan, Ömer Lütfi: "The Price Revolution of the Sixteenth Century: A Turning Point in the Economic History of the Near East", çev. Justin McCarthy, International Journal of the Middle East Studies, 6 (1975), s. 3-28.

Dağtekin, Emine Ekinci: “Coğrafi İşaret Olarak Diyarbakır Bazalt Taşı ve Tescili”, Elektronik Sosyal Bilimler Dergisi, 17/66 (2018), s. 851-860.

Demir, Aydoğan, Gültekin Teoman, Şakir Çakmak: "Numismatischer Teil (Selim I.Selim II.)" Der Münzschatz von Beçin, I, ed. Rahmi Hüseyin Ünal, Fritz Krinzinger, Michael Alram, Şule Pfeiffer-Taş, Wien: Verlag der Österreichischen Akademie der Wissenschaften 2010, s. 129-133.

Demir, Aydoğan, Gültekin Teoman, Şakir Çakmak: "Numizmatik-I.Selim’den II. Selim’e Kadarki Dönem”, Beçin Definesi, I, ed. Rahmi Hüseyin Ünal, Fritz Krinzinger, 
Michael Alram, Şule Pfeiffer-Taş, Ankara: Türkiye Bilimler Akademisi 2015, s. 121-124.

Ender, Celil: Başbakanlık Devlet Arşivleri Osmanl Arşivi'ndeki Nümismatik ile İlgili Belgeler Kataloğu (Darphaneler, İlgili Kuruluşlar, Madenler, Meskûkât, Kaime, Madalya, Nişanlar vb.) - Documents of Numismatic Importance in the Ottoman Archives (Coinage-Medals and Orders-Mints and Their Administration-Mint Masters and Superintendens-Stampers of Imperial Monograns (Tü̆ra) -Counterfeiters etc.), İstanbul: Türk Numismatik Derneği Yayınları 1996.

Ergenç, Özer: "XVI. Yüzyılın Sonlarında Osmanlı Parası Üzerinde Yapılan İşlemlere İlişkin Bazı Bilgiler”, Türkiye İktisat Tarihi Üzerine Araştırmalar, ODTÜ Gelişme Dergisi Özel Sayısı, (1978), s. 86-97.

Gerber, Haim: "The Monetary System of the Ottoman Empire", Journal of the Economic and Social History of the Orient, 25 (1982), s. 308-24.

Gökbilgin, M. Tayyib: “Mehmed III.”, İslâm Ansiklopedisi (İA), VII, (İstanbul 1997), 535-547.

Günay, Ramazan: 259 Numaralı Hicri 1006-1008 (Miladî 1598-1600) Taribli Mardin Şer'iyye Sicilinin Transkripsiyon ve Değerlendirmesi, (Yayınlanmamış Yüksek Lisans Tezi) Dicle Üniversitesi Sosyal Bilimler Enstitüsü, 2002.

Hammer-Purgstall, Joseph von: Geschichte des Osmanischen Reiches, IV, Graz: Akad. Dr.-u. Verl.-Anstalt 1963 (Tipkıbasım).

Hüsch, Walter, M. Poniatowski, H. Wilski: “The Fineness of Ottoman Akces”, Oriental Numismatic Society Newsletter, 155 (1998), s. 11-13.

İnalcık, Halil: "Introduction to Ottoman Metrology", Turcica, 15 (1983), s. 311-348.

İnalcık, Halil: An Economic and Social History of the Ottoman Empire, vol. I: 1300-1600, Cambridge: Cambridge University Press 1994.

İnalcık, Halil, Suraiya Faroqhi, Bruce McGowan, Donald Quataert, Şevket Pamuk (eds.): An Economic and Social History of the Ottoman Empire, vol II: 1600-1914, Cambridge: Cambridge University Press 1994.

İnalcık, Halil: “İki Rakip Kardeş: Altın ve Gümüş. Two Rivals: Gold and Silver”, Altının İktidarı, İktidarın Altınları. Yapı Kredi Para Koleksiyonu Altın Sikke Sergisi - Power of Gold, Golds of Power, Exhibition of Gold Coins Yapr Kredi Collection 10.9.2004 26.2.2005, ed. Oğuz Tekin, İstanbul: Yapı Kredi Yayınları 2004, s. 143-157.

İslamoğlu-İnan, Huri: The Ottoman Empire and the World-Economy, Cambridge: Cambridge University Press 1987.

Kabaklarlı, Necdet, Metin Erüreten: "Osmanlı Paralarında Ölçü ve Ayar / The Unit of Measurement and Scales of Ottoman Coins”, Necdet Kabaklarl1, Mangzr. Tire'de Darpedilen Osmanlı Bakır Paralar//Ottoman Copper Coins Minted in Tira, 1411-1516, İstanbul: Uşak Belediyesi Kültür Hizmeti 2007, s. 128-136 (Ek 2/Appendix II). 
Kafadar, Cemal: "Prelude to Ottoman Decline Consciousness: Monetary Turbulence at the End of the Sixteenth Century and the Intellectual Response", Osmanl Araştırmalar, 51 (2018), s. 265-295.

Kafadar, Cemal: "Les troubles monétaires de la fin du XVIeme siecle et la prise de conscience ottomane du déclin”, Annales. Économies, Sociétés, Civilisations, $46^{\mathrm{e}}$ année, 2 (1991), s. 381-400.

Kafadar, Cemal: When Coins Turned into Drops of Dew Bankers Became Robbers of Shadows. The Boundaries of Ottoman Economic Imagination at the End of the Sixteenth Century, (Yayımlanmamış Doktora Tezi) Montreal: McGill University, 1986.

Kütükoğlu, Mübahat: “1009 (1600) Tarihli Narh Defterine Göre İstanbul'da Çeşitli Eşya ve Hizmet Fiyatları", İstanbul Üniversitesi Edebiyat Fakültesi Tarih Enstitüsü Dergisi, 9 (1978), s. 1-85.

Öztürk, Yücel: Osmanl Hakimiyetinde Kefe (1475-1600), Ankara: Kültür Bakanlığı Yayınları 2000.

Pamuk, Şevket: Osmanlı İmparatorluğu’nda Paranın Taribi, İstanbul: Tarih Vakfı Yayınları 1999.

Pamuk, Şevket: A Monetary History of the Ottoman Empire, Cambridge: Cambridge University Press 2000.

Pamuk, Şevket: "The Ottoman Monetary System and Frontier Territories in Europe, 1500-1700”, International Journal of Turkish Studies, 9 (2003), s. 175-82.

Pamuk, Şevket: "Prices in the Ottoman Empire, 1469-1914", International Journal of Middle East Studies, 36 (2004), s. 451-468.

Pfeiffer-Taş, Şule: Inhaltsangabe der Chronik Selanikis und Vergleich mit dem Werk Naimas (April 1594-Jaenner 1597), (Yayımlanmamıs Doktora Tezi) Universität Wien, 1993.

Pfeiffer-Taş, Şule: "Zur Geldgeschichte im Osmanischen Reich in der Zeit von Selim I. bis Ahmed I.”, Der Münzschatz von Beçin, I, ed. Rahmi Hüseyin Ünal, Fritz Krinzinger, Michael Alram, Şule Pfeiffer-Taş, Wien: Verlag der Österreichischen Akademie der Wissenschaften 2010, s. 70-116.

Pfeiffer-Taş, Şule: “16. Yüzyılda Bir Osmanlı Para Birimi: Kara(ca) Akçe/ An Ottoman Currency in 16th Century: Kara(ca) Akçe", 12th International Congress of Ottoman Economic and Social History (ICOSEH) 11-15 July 2011, Retz (Lower Austria), Abstracts, s. 66-67.

Pfeiffer-Taş, Şule: “The Coin Hoard of Ottoman Emir Süleyman in Tire Museum”, Proceedings of the 14th International Congress of Turkish Art, Collège de France, Paris, 19-21 September 2011, Paris 2013, s. 627-641.

Pfeiffer-Taş, Şule: “The Numismatic, Metrological and Fiscal Assessment of Şahi, an Important Coin of the Reign of Murad III", 13th International Congress of Ottoman 
Social and Economic History (ICOSEH) 1-5 October 2013 Universidad de Alcalá, Spain, (Alcalá 2013), Abstracts, s. 89-90.

Pfeiffer-Taş, Şule: "New Remarks Regarding Ottoman Monetary History in Light of the Akçe-Coins of Murad III.", Bildiriler-Proceedings /Birinci Uluslararası Anadolu Para Tarihi ve Numismatik Kongresi 25-28 Şubat 2013-First International Congress of the Anatolian Monetary History and Numismatics 25-28 February 2013, ed. Kayhan Dörtlük, Oğuz Tekin, Remziye Boyraz Seyhan, Antalya: Akdeniz Medeniyetleri Araştırma Merkezi Yayınları 2014, s. 489-507.

Pfeiffer-Taş, Şule: “I. Selim’den I. Ahmed'e Kadarki Dönemde Osmanlı Devletinin Para Tarihi”, Beçin Definesi, I, ed. Rahmi Hüseyin Ünal, Fritz Krinzinger, Michael Alram, Şule Pfeiffer-Taş, Ankara: Türkiye Bilimler Akademisi 2015, s. 65-108.

Pfeiffer-Taş, Şule, Nikolaus Schindel: "Ein Münzkonvolut aus der Regierung des osmanischen Sultans Ahmed I. (1603-1617) im Museum von Tire”, Wiener Zeitschrift für die Kunde des Morgenlandes, 99 (2009), s. 249-280.

Pfeiffer-Taş, Şule, Nikolaus Schindel: "The Beçin Coin Hoard and Ottoman Monetary History in the Late $16^{\text {th }} /$ Early $17^{\text {th }}$ Century", Journal of the Economic and Social History of the Orient, 56, 4-5 (2013), s. 653-671.

Rodrigues, Martha, Manfred Schreiner: "Non-Destructive Analysis of the Hoard of Beçin", Der Münzschatz von Beçin, I, ed. Rahmi Hüseyin Ünal, Fritz Krinzinger, Michael Alram, Şule Pfeiffer-Taş, Wien: Verlag der Österreichischen Akademie der Wissenschaften 2010, s. 526-538.

Redhouse, Sir James: Yeni Türkçe-İngilizce Sözlük / New Redhouse Turkish-English Dictionary, İstanbul: Redhouse Yayınevi, 1983.

Sahillioğlu, Halil: "Osmanlı Para Tarihinde Dünya Para ve Maden Hareketinin Yeri 13001750”, ODTÜ Gelişme Dergisi, Özel Sayısı (1978), s. 1-38.

Sahillioğlu, Halil: Kuruluşundan XVIII. Asrın Sonlarına Kadar Osmanlı Para Taribi Üzerinde Bir Deneme, (Yayınlanmamış Doktora Tezi) İstanbul Üniversitesi, 1958.

Sahillioğlu, Halil: Bir Asırlık Para Taribi (1640-1740), (Yayınlanmamış Doçentlik Tezi) İstanbul Üniversitesi İktisat Fakültesi, 1965.

Sahillioğlu, Halil: Studies on Ottoman Economic and Social History, İstanbul: IRCICA 1999.

Schindel, Nikolaus, Şule Pfeiffer-Taş: "Numismatischer Teil - Murad III. bis Ahmed I.", Der Münzschatz von Beçin, I, ed. Rahmi Hüseyin Ünal, Fritz Krinzinger, Michael Alram, Şule Pfeiffer-Taş, Wien: Verlag der Österreichischen Akademie der Wissenschaften 2010, s. 134-389.

Schindel, Nikolaus, Şule Pfeiffer-Taş: "Numizmatik - III. Murad'dan I. Ahmed'e”, Beçin Definesi, I, ed. Rahmi Hüseyin Ünal, Krinzinger Fritz, Alram Michael, Pfeiffer-Taş Şule, Ankara: Türkiye Bilimler Akademisi 2015, s. 125-378. 
Schindel, Nikolaus, Şule Pfeiffer-Taş, Gültekin Teoman, Leonard Reis: "Islamische Münzen”, Der Münzschatz von Beçin, II, ed. Rahmi Hüseyin Ünal, Fritz Krinzinger, Michael Alram, Şule Pfeiffer-Taş, Wien: Verlag der Österreichischen Akademie der Wissenschaften 2010, s. 3-192.

Selânikî Mustafa Efendi: Tarih-i Selânikî, I-II, haz. Mehmet İpşirli, İstanbul: İstanbul Üniversitesi Edebiyat Fakültesi Yayınları 1989.

Srećković, Slobodan: Akches, vol. II: Mehmed II Fatih-Selim I Yavuz, 848-926 AH, Belgrade: Slobodan Srećković 2000.

Srećković, Slobodan: Akches, vol. IV: Selim II Sar1-Murad III, 974-1003 AH, Belgrade: Slobodan Srećković 2005.

Tezcan, Baki: "The Ottoman Monetary Crisis of 1585 Revisited”, Journal of the Economic and Social History of the Orient, 52 (2009), s. 460-504.

Tietze, Andreas: Muștafā 'Āli's Counsel for Sultans of 1581, I-II, Wien: Verlag der Österreichischen Akademie der Wissenschaften, 1979-1982.

Ünal, Rahmi Hüseyin, Fritz Krinzinger, Michael Alram, Şule Pfeiffer-Taş (ed.): Der Münzschatz von Beçin, I-II, Wien: Verlag der Österreichischen Akademie der Wissenschaften 2010 .

Ünal, Rahmi Hüseyin, Fritz Krinzinger, Michael Alram, Şule Pfeiffer-Taş (ed.): Beçin Definesi, I-II, Ankara: Türkiye Bilimler Akademisi 2015.

Yeniçeri, Celal: "Bâc”, TDV İslâm Ansiklopedisi, IV, (1991), s. 411-413.

Zenker, Julius Theodor: Türkisch-Arabisch-Persisches Handwörterbuch - Dictionnaire Turc-Arabe-Persan, I-II, Hildesheim-New York: Georg Olms Verlag 1979 [Leipzig 1866'dan 2. Tipkıbasım]. 